\title{
THE EURO AND EUROPEAN FINANCIAL MARKETS
}

by

Robert N. McCauley

William R. White

May 1997

BANK FOR INTERNATIONAL SETTLEMENTS

Monetary and Economic Department

BASLE 
BIS Working Papers are written by members of the Monetary and Economic Department of the Bank for International Settlements, and from time to time by outside economists, and are published by the Bank. The papers are on subjects of topical interest and are technical in character. The views expressed in them are those of their authors and not necessarily the views of the BIS.

(C) Bank for International Settlements 1997

CH-4002 Basle, Switzerland

Also available on the BIS World Wide Web site (http://www.bis.org).

All rights reserved. Brief excerpts may be reproduced or translated provided the source is stated. 


\title{
THE EURO AND EUROPEAN FINANCIAL MARKETS*
}

\author{
by
}

\author{
Robert N. McCauley \\ William R. White
}

May 1997

\begin{abstract}
This study argues that the introduction of the euro would have a more immediate and direct impact on European bond markets than on European banking markets. The single currency would create a single private yield curve in the near term and could also lead to a more integrated government bond market. While the immediate impact of the euro for banking markets would be limited, the switch over time by European corporations from bank debt to bond debt would come on top of the competitive challenge that European banks already face. The need for banks to adjust raises a number of potential issues for public policy in Europe, some of which may have broader international implications.
\end{abstract}

* We would like to thank, without implicating them and in alphabetical order: Palle Andersen, Stephan Arthur, Jeremy Barson, Florence Béranger, Henri Bernard, Claudio Borio, Dierk Brandenburg, Clifford Dammers, Phil Davis, Angelika Donaubauer, Charles Goodhart, Gregor Heinrich, André Icard, Serge Jeanneau, Frederick Marki, Danielle Nouy, Denis Pêtre, Kostas Tsatsaronis and Jürgen von Hagen. 



\section{Contents}

Summary

1. The euro and the balance of competitive pressures in European financial markets

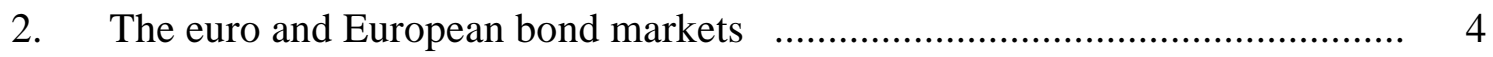

2.1 The transition costs of monetary union ................................................ 4

2.2 The euro and private money and bond markets ............................... 5

2.2.1 The private yield curve in euros ................................................ 5

2.2.2 Increased competition in underwriting private and foreign bonds 7

2.3 The euro and European government bond markets ….......................... 9

2.3.1 Prospects for an integrated government bond market in the core of Europe ......................................................................... 9

2.3.2 Liquidity and cooperative debt management: the evidence to date 11

2.3.3 Re-rating high-debt European sovereigns: lessons from Canada? 12

2.4 Implications ..................................................................... 15

2.4.1 Internal implications ......................................................... 15

2.4.1.1 The gradual process of portfolio diversification ............... 15

2.4.1.2 Growth of securities markets in the euro area .................. 16

2.4.2 International implications: investment and borrowing in the euro 18

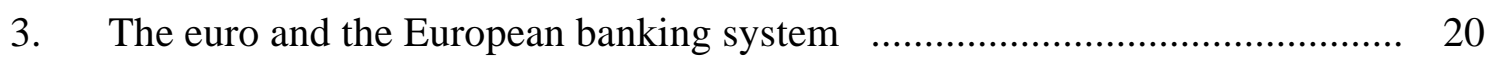

3.1 The transition costs of monetary union ......................................... 20

3.2 The euro and increased competition in banking ................................. 22

3.3 The need for adjustment and potential difficulties f.......................... 25

3.4 Implications ........................................................................ 27

3.4.1 Internal implications .......................................................... 27

3.4.1.1 Incentive structures for sound banking ......................... 27

3.4.1.2 Preventing and managing banking problems ................. 29

3.4.1.3 Interest rate effects and financial stability ...................... 31

3.4.2 International implications ...................................................... 32

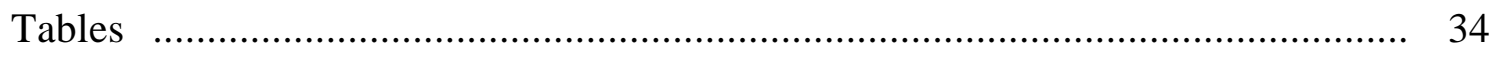

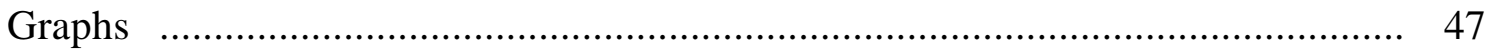

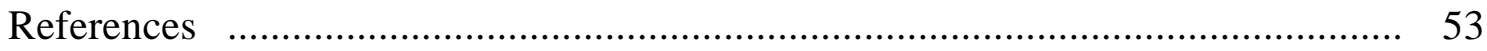





\section{Summary}

Many uncertainties as regards timing, scope and other issues still surround the introduction of a single currency in Europe. Nevertheless, the event seems probable enough, imminent enough and important enough to warrant some consideration of what the effects might be on the structure of European financial markets and the implications of such changes both within Europe and for the international financial system.

The story-line in this paper is dynamic but simple. The starting-point (Section 1 below) is that European-based financial firms are already under significant competitive pressure to restructure. Moreover, existing forces of technological change and deregulation affecting cross-border activity (the First and Second Banking Directives) must eventually cause those pressures to intensify, even if the effects to date on international competition in corporate and retail banking have been limited. However, the introduction of the euro seems likely to be a catalyst for change going well beyond the need to absorb the direct costs of transition. It seems probable that it will play an important role in stimulating the growth of a much larger and more liquid securities market in Europe (both private and public) (Section 2). This could be a significant new source of competitive pressure for banking firms providing traditional forms of intermediated credit in Europe. While the bond market in euros is likely to attract both more international investment and more issuance in that currency, implying an enhanced role for the euro in the international financial system, the associated profits may be rather highly concentrated. The direct influence of the euro in stimulating international competition among banks for traditional kinds of business (Section 3) will be a second new source of competitive pressure, but in itself likely to be of a lower order of importance. Existing legal, fiscal, regulatory and cultural factors will continue to divide markets. Nevertheless, it is not difficult to tell a dynamic story in which increased competition among banks, aided by ongoing disintermediation, leads to increased pressure for more harmonisation and in turn still more competitive pressure.

Should such a competitive environment emerge, it will be all the more important to have in place adequate incentive structures and supervisory arrangements to promote sound banking practices. Issues having to do with managing banking problems in a single currency area, should they occur, are also important but of course cannot be addressed without recognising the complications posed by moral hazard problems. Whatever Europeans choose to do in these areas, there will also be international implications. Given the nature of integrated international financial markets, any adjustment problems which might occur could have spillover effects beyond Europe. Globally integrated financial markets also imply that the approach taken to problems of systemic risk within Europe should be coherent with any approach adopted more globally. While this is in fact already the case, the bargaining dynamics of achieving global agreements could well be different in the future should Europe increasingly speak with a single voice. 


\section{The euro and the balance of competitive pressures in European financial markets $^{1}$}

If European banks are about to enter a period of enhanced competition, the starting position for many banks is not particularly strong. As indicated in Table 1, the rate of return on the assets of continental European banks rebounded in 1995 and, according to preliminary reports, it rose further in 1996. However, this should not overshadow two other trends. The rate of return continues to be relatively low in some countries (compared with US, UK and restructured Scandinavian banks) ${ }^{2}$ and profits seem to have been trending down since the mid-1980s (see Table 2). Net interest margins have tended to narrow, and loan loss provisions have been high. ${ }^{3}$ Reflecting these realities, the ratio of bank share prices to general stock price indices has been falling in most European countries (see Table 3) and downgradings of continental banks by rating agencies have become more common (see Graph 1), even if credit ratings remain relatively high. In sum, there is at least a prima facie case that a significant degree of restructuring is required, leading to some withdrawal of capital from the industry and some concentration of that capital which remains.

There are also a number of reasons for believing that competitive pressures in the European financial industry are likely to increase significantly. Technological change is affecting the financial services industry everywhere, lowering the costs of both information and transactions. This challenges the basis of traditional relationship banking and encourages securitisation as well as competition from non-banks for corporate and retail banking business. The growing interest in many European countries in private pension schemes, and other means to encourage savings on the part of a rapidly ageing population, will work in the same direction. Finally, the process of financial deregulation in Europe has been under way for almost 30 years, culminating in the Capital Liberalisation Directive of 1988 and the Second Banking Coordination Directive which came into effect on 1st January 1993. The explicit purpose of these Directives was to encourage a heightened level of international competition in the member countries of the European Union.

What is somewhat surprising, in light of all these forces for change, is how little impact they have had to date on the structure of the European financial industry, which continues to be

1 It is appropriate to begin the paper with a health warning. We are trying to provide a brief summary of some very broad trends in the European financial industry. We recognise that, in the process, assertions will be made that do not apply at all (or only in part) to banks from particular national jurisdictions. For individual banks, broad statements may be even less applicable.

2 In the late 1980s, a lower cost of equity for German banks allowed them to earn as much as a 20 basis point lower return on their (risk-adjusted) assets than their UK or US competitors. See Zimmer and McCauley (1991).

3 Much of this can be related to losses on loans collateralised with commercial property. The value of such property fell sharply through the first half of the 1990s in many continental European countries (albeit with wide regional variations), though the implications for the profit and loss account tended to be recognised only with a lag. 
basically "national" in the provision of corporate and retail banking services. ${ }^{4}$ Moreover, it remains the case that banking products in many continental European countries are still significantly overpriced relative to those supplied by low-cost providers elsewhere in Europe. ${ }^{5}$ The reason for this is that there also exist many forces resisting change. One important consideration is that the industry has not had very many years to react to recent deregulatory initiatives, and has had to adjust as well to a rather sluggish macroeconomic environment. With time, these impediments to change should disappear. However, other impediments to international competition are likely to be longer-lasting. There continue to be significant differences across European countries in the legal, tax, regulatory and supervisory frameworks within which financial firms have to operate. Different accounting and reporting procedures, technical standards, labour practices and cultural preferences further distinguish national markets. Finally, the continuing and important role of the state in the banking business in many continental European countries (see Table 4) is also a force acting to suppress international competition.

In the rest of this paper, we speculate on how the introduction of a single currency in Europe might tilt the balance of forces described above, potentially acting as a catalyst for pent-up and significant change in the structure of European and indeed global financial markets. We focus on two principal possibilities. First, bond markets may gain in strength, depth and liquidity from the introduction of the euro and this will be to the disadvantage of those supplying traditional intermediated credit. Second, the euro will lead to transitional costs and an increase in European intrabank competition at a time when continental banks are already struggling to cope with global competitive pressures and other European Union initiatives directed towards the single market. While, for analytic convenience, we treat separately these two threats to the competitive status quo in European banking, there could be strong interactions between them; lower credit ratings for some banks could encourage direct recourse to financial markets, still stronger competitive pressures, further harmonisation, yet more competition and so on.

The possible implications of these changes for domestic financial stability and European public policy need to be considered. Moreover, given the size of European financial markets, and their close links with the rest of the world, the repercussions elsewhere also need to be considered. The possibility that non-Europeans might also have low-cost access to a large and liquid securities market denominated in euros has international implications. Finally, the need to cope with potentially

4 See Economic Research Europe Ltd. (1996). The market for wholesale banking services is intensely competitive and highly international. However, this reflects the influence of offshore markets and euromarkets much more than regulatory change within Europe itself.

5 A Price Waterhouse study (see Price Waterhouse (1988)) documented the extent of these price deviations. The more recent study by Economic Research Europe Ltd. (1996) indicated that not a great deal had changed on average, although the prices of some financial services had fallen discernibly in some of the countries which had been most highly regulated to begin with. 
significant changes in financial structure within the euro area raises supervisory and related issues with broader international dimensions.

\section{The euro and European bond markets}

Many analysts of the effect of the euro on European bond markets concede that integration of the private bond market in euros could proceed rapidly. Nevertheless, it is often contended that the government bond market in euros would be likely to remain fragmented, with significant, persistent and variable credit spreads marking one issuer's bonds off from those of another. What follows partly agrees and partly disagrees with each proposition. The business of pricing private credits in euros should benefit (and almost already benefits) from a common reference yield curve, and thereby from heightened competition among underwriters of new issues. In the pricing of government debt, prospects for integration in the trading of the bonds of most creditworthy governments look brighter than is generally acknowledged. At the same time, the euro may sharpen credit differences across the full range of governments participating in monetary union.

After discussing the short-term costs of the transition to the euro, we assess the likely effects of the euro on European bond markets, and then we draw some implications. A fully integrated bond market will require a long process of legal, regulatory and behavioural change that would free institutional investors to invest across the euro area. Given such integration, an implication internal to the euro area is the probable alteration of the calculus of costs and benefits of bond issuance by European corporations, tilting the balance of corporate credit away from banks and towards the bond market. From an international perspective, a deeper, more liquid bond market can be expected to attract international asset and liability managers to increase the share of euro-denominated securities in their portfolios in relation to the sum of the shares of the euro's constituent currencies.

\subsection{The transition costs of monetary union}

The transition to monetary union confronts the securities industry with direct costs and legal risks that at this stage appear modest. Market-makers in European securities have reported that the direct costs of making the transition to the single currency would be quite moderate. A study commissioned by the International Securities Market Association, based on a survey of over 1,000 market participants, put the range at between ECU 110,000 and ECU 8 million per firm. ${ }^{6}$ This worked out to an average of $0.058 \%$ of the total operating costs of financial institutions. This is a tiny fraction compared with some of the estimates from banks (some of which may include these securities firms' conversion costs; see below). In addition, some firms, "such as large brokerage firms", reported

6 See Scobie (1997), p. 48. No response rate was specified. 
anticipated job losses of 15-25\%, although others, "particularly large investment banking firms", anticipate no reductions in the workforce.

In addition, swap dealers face the risk that counterparties might plead that they cannot fulfil (losing) swap contracts owing to the disappearance of the relevant currency. One estimate is that 14-15\% of swap contracts extend beyond 1999 and "need to be tightened up with respect to the conversion to the euro". ${ }^{7}$ Legal counsel of securities firms in Europe have been working with Brussels to ensure continuity of contract, but questions remain as to how New York State courts might respond to such cases (see also Section 3.1 below). In sum, total transition costs in the fixed income markets appear modest.

\subsection{The euro and private money and bond markets}

The euro will create a single private yield curve across the euro area. As a result, the field of competition among underwriters will open up and issues should enjoy better pricing.

\subsubsection{The private yield curve in euros}

Ranging from an overnight rate, which would be strongly affected by the repo operations of the European Central Bank (ECB), to interbank offered rates of maturities from one week to one or two years, a single reference money market yield curve can be expected. It is an open question whether the reference yields for the euro money market will be established onshore or offshore. The location of the banks that will be polled for the most widely used reference rates may depend on whether the ECB uses unremunerated reserve requirements as an instrument of monetary policy. At present, French franc futures contracts are based on PIBOR, the Paris rates, while the most heavily traded Deutsche mark (and US dollar) contracts are based on London rates, rather than Frankfurt (or New York) rates, owing to the reserve requirements assessed in Frankfurt (and formerly assessed in New York). In the absence of reserve requirements, significant deposit insurance premia or the like, the choice of whether to collect rates from banks located in Paris, Frankfurt, Amsterdam, London or Zurich will under normal circumstances not make any difference in terms of the rates obtained. ${ }^{8}$ Rather, the identity of the banks included in the poll would make a difference (as the Japan premium

7 See Ibid., p. 66.

8 The London International Financial Futures and Options Exchange announced in March 1996 that March 1999 eurocurrency contracts for the Deutsche mark, pound sterling and Italian lira would provide for settlement in euros if these currencies were irrevocably fixed to the euro by three weeks before contract expiry (see "EMU: LIFFE's response", LIFFE Market Monitor, no. 7, 3rd April 1996). Rates on euros would be collected by the British Bankers' Association in London, according to Gregorio (1996, p. 5). Similarly, the MATIF has made provision in Article 12 of the regulations for the three-month PIBOR futures contract for the replacement of the French franc with the euro (see Scobie (1997), p. 65). Such moves already anticipate a market in which prime names from across the currency area would be able to fund themselves, and manage their interest rate exposure in euros, at rates that would be determined area-wide. 
has recently reminded us). That is, a bank might at times or regularly pay a premium over the average interbank rate offered by prime banks, but such risk premia would depend more on the bank's risk profile than on its location. In sum, a single private money market yield curve seems to be in the offing, and the market's choice of reference rates between onshore and offshore rates will depend on the ECB's reserve requirements.

Whether onshore or offshore, the euro money market is likely to prove a very liquid market from its inception. By liquidity is meant the ability to transact large amounts at short order without moving the market against oneself. Operationalising this concept presents a real challenge, but transactions measures such as bid/ask spreads and trading volumes probably better indicate liquidity than the size of underlying asset stocks. Table 5 shows derivative transactions in private money market instruments. Focusing on these has the advantage of measuring the transactions with the lowest costs. On this view, even a narrow monetary union would create a money market that would, at current exchange rates, surpass the scale of the yen money market in derivative transactions, and thus probably in liquidity. Admittedly, this comparison may flatter the euro if a substantial fraction of money market transactions in the French franc represents one leg of matched transactions in marks. In any case, a considerable gap would remain between the euro and the dollar in this respect, with futures and forward transactions of at least $\$ 40$ trillion per year in Europe, compared with eurodollar transactions in excess of $\$ 100$ trillion. At such scale it is reasonable to expect that three-month euro futures would offer greater liquidity than do Deutsche mark futures, especially in contracts settling four to eight quarters ahead (see Karsenti (1996)).

At longer maturities, the most frequently used private reference rates will be the yields on the fixed rate side of interest rate swaps. These standard and liquid prime-name rates extend from two years out to ten years in maturity and already serve as the most important private reference rates in today's bond markets. The convergence among these swap yields for contracts in Belgian francs, marks, Dutch guilders and French francs over the past two years (see Graph 2) carries the strong message that market participants attach a high probability to stable exchange rates among these currencies. ${ }^{9}$ This inference is supported by the possibility that, if exchange rates were expected to move, one could contract to pay fixed (and receive floating) in the weak currency and to receive fixed payments (and pay floating) in the strong currency. The swap market is precisely where such private arbitrage/speculation takes place at the lowest transaction costs. (In this respect, the swap yield curve represents an extension to longer maturities of the private money rate LIBOR.) At the inception of monetary union, the currently nearly identical swap curves will collapse into one single swap curve.

9 See BIS (1996a), pp. 112-113 for the use of swap rates to assess the market outlook for European monetary union. See also De Grauwe (1996). 
The private capital market in euros is also likely to prove to be a very liquid market from its inception. On current evidence, even a narrow monetary union would offer a swap market about as active as those in the US dollar and in the Japanese yen (see Table 6). Even recognising that convergence trades are providing a temporary boost to the European transactions (see Bradbery (1996) and Burgess (1996), p. 4), the euro looks set to offer a private yield curve with world-class depth, breadth and liquidity.

In view of the uncertain prospects for the integration of government bond markets in the euro area, discussed below, some analysts have suggested that the swap yield curve might perform a benchmark role in Europe (see Adler (1996), Huteau (1997), Karsenti (1996) and Krämer (1996)). Normally, one thinks of the benchmark as the lowest yield, with other yields quoted (and in effect determined) as spreads over the benchmark. However, in principle, the bonds of various governments could be priced as spreads under the swap yield curve. The problem with this suggestion is not a formal but a practical one. Transactions in swaps and swaptions, while very large at trillions of dollars equivalent per year, pale in comparison to the tens of trillions of dollars of transactions in government bonds, government bond futures and government bond options, as will be demonstrated below. As things stand, it is hard to imagine the private yield curve in euros serving as the benchmark for government as well as private risks in the European bond market. ${ }^{10}$

\subsubsection{Increased competition in underwriting private and foreign bonds}

If multiple currencies in Europe tend to segment its bond markets, keener competition in the bond market should result from monetary union. As background, consider the range of factors that bear on competition in a primary bond market. One can conceive of bond underwriters drawing their competitive advantage from one of three sources: relations with the issuers, general understanding of the money and bond markets, including the direction of rates and associated movements in spreads, and relations with end-investors. Government bond auctions seek to limit the influence of the first factor, and studies of the US Treasury market have in fact emphasised "a large customer base with heavy order flow" as the principal source of competitive advantage (see Ruocco et al. (1991)).

The source of competitive advantage bears directly on the question of the effect of monetary union. If relations with issuers are key, then the euro will tend not to disturb competition. But if an underwriter benefits from understanding the direction of national interest rates, or from access to investors, then the euro will sharpen competition. No longer will a French bank have a natural edge in understanding the monetary and fiscal policies that can move the French bond market, and eventually a French bank will not be able to use its French investor base to win deals.

10 It must be admitted in this connection that transactions in US Treasury bills and Treasury bill futures also exceeded by a wide margin transactions in bank deposit futures in the early 1980s, only to be left behind by the growth of eurodollar futures. 
One test for whether the euro will sharpen competition in the bond market, therefore, is to check whether currency makes a difference in the choice of underwriter, controlling for the nationality of the bond issuer. The test can be performed on the international bond market for reasons both of data availability and of relevance. The data are relevant because the international bond market is, to a considerable extent, the euro bond market to be: one-quarter of the outstanding issues feature EU issuers in EU currencies, and a substantial fraction of investors are EU institutional investors. An early study of this question documented a decline of issuer-underwriter relations and a rise in the role of currency in the selection of underwriter (see Courtadon (1985)). A more recent study (Balder et al. (1991)) found a strong association between the nationality of the lead underwriter and the currency denomination of the bond for all but eurodollar issues, where customer relations seemed important. Most recently, Dermine (1996) points to the dominance of home-country lead managers in the league tables by currency sector, without distinguishing the influence of customer from that of currency.

An analysis of the effect of customer nationality and the currency denomination of the bond on the choice of lead managers (dubbed bookrunner after a period of title inflation) points to the strong predominance of currency effects over issuer effects in European currency sectors (see Table 7). ${ }^{11}$ German, French, UK and Dutch underwriters capture fairly close to the same share of the business of home-country issuers and foreign issuers, but show huge differences in market shares in their home currencies as against all other currencies. As found previously, the influence of customer and that of currency is much more balanced for US underwriters.

The upshot of this analysis is that separate currencies in Europe have tended to segment the international bond market and that, over time, currency has shown more persistence as a factor bearing on competition than have relations between customers and underwriters. Brown (1996, p. 4) argues that the competitive challenge is not symmetrical: "the advantage German banks have had in the no. 2 international capital market, the euro-DM market, will not carry over into the euro capital market". As underwriter competition becomes sharper under the euro, the cost of corporate issuance of debt should decline. Another factor that could ease the marketing of European corporate bonds would be a more integrated European market for government bonds. To this we turn before discussing the implications of cheaper bond issuance.

11 The association of currency of issue and nationality of underwriter, however, seems weaker in 1996 than it was in 1983 for the mark, pound and guilder sectors (see Courtadon (1985), pp. 40-41). And even today, some sectors of the international bond market show a stronger influence of customer ties, in contrast to the general finding in the text. For instance, the Neue Zürcher Zeitung of 20th February 1997, p. 25, reports that the Japanese big four securities firms plus Tokyo-Mitsubishi and Kankaku captured $46.5 \%$ of the underwriting mandates of Japanese issuers in the Swiss franc market, more than the $39 \%$ captured by the Swiss big three plus Gotthard Bank. But this SF 7.4 billion sector features small, often equity-related, issues, and the customer base may include a large proportion of Japanese accounts. 


\subsection{The euro and European government bond markets}

The euro is likely to exert both centripetal and centrifugal forces on the European government bond market. The market's demand for liquidity, and its reward for policies that contribute to liquidity, provide powerful integrative forces. At the same time, the unification of monetary policy, and the re-evaluation of government risk in terms of fiscal position rather than international asset position, might highlight credit differences that could widen pricing distinctions. Markets might, therefore, simultaneously make little of differences among the most creditworthy of European governments while making much more of a distinction between these and more heavily indebted governments. Thus the centripetal and centrifugal forces need not cancel each other out.

\subsubsection{Prospects for an integrated government bond market in the core of Europe}

The countries judged most likely to enter monetary union in 1999 are among those which tend to enjoy the highest credit ratings (see Table 8). Moreover, bond buyers currently price the bonds of these governments in a very similar manner. To see this similarity, recall the convergence of private yields, as measured by interest rate swaps, in the Belgian, Dutch, French and German bond markets. Lower than these, more or less double-A-rated, private yields are the respective government yields, which are solidly triple-A-rated for Dutch, French and German bonds.

The pricing of generic private risk in relation to government risk bears a great similarity in bond markets along the Rhine (see McCauley (1996)). The spreads between the yield on a ten-year interest rate swap and the yield on a ten-year government bond are unusually close in these three bond markets, where these spreads have converged to a common level of about -20 to -30 basis points (see Graph 3). Never in the history of the swap market has this spread been so similar, for so long, across so many markets.

These measured credit differences are small. In particular, they are small in relation to the potential liquidity benefits of practically fungible trading of European government bonds. To many observers, such trading is inconceivable because it would require accepting "joint and several liability" of the relevant EU governments for each other's debt. Given all the associated moral hazard this is not likely to happen very soon. Such a legal arrangement would indeed be sufficient to unify the bond markets of the participating governments. But is it necessary to render the "sovereign debt of EMU participants largely substitutable products" (see Mayer (1996), p. 10)?

One operational criterion of an integrated bond market is that it be served by a single futures contract (or, more precisely, a single contract at each maturity). One way to achieve such a market is by virtue of a single issuer becoming the benchmark and its obligations serving as the basis for a futures contract. Thus today, the German government bond contract is used by dealers in Dutch and Belgian government debt for hedging, although changes in the yield spreads render these hedges 
imperfect (i.e. introduce "basis risk"). Much market commentary is focused on which government will attain benchmark status. Cited in favour of France's debt assuming such a role is the liquidity and size of individual issues, as well as the French Treasury's pre-announced issuance calendar. Cited in favour of Germany's debt assuming such a role is its greater size and the greater turnover in the Bund futures. The choice of a single benchmark issuer, however, implies purchasing credit homogeneity at the expense of imbuing only a narrow range of bonds with the liquidity benefits of an associated futures contract. Greater liquidity might result from a contract in which a number of issuers' bonds might be delivered into the same futures contract, so-called multiple-issuer deliverability (see Duesing (1997), Fox (1996) and Mazzucchelli et al. (1996)). However, the art of contract design is to avoid permitting such a wide range of signatures as to bring a sort of Gresham's Law into play, according to which the worst signature drives out the other signatures (see Box 1 below).

\title{
Box 1
}

\section{The ECU bond future: a cautionary tale}

\begin{abstract}
Mention to London financiers the possibility of a single bond future based on a number of European government bonds, and they often recall the case of the ECU bond contract (see Mazzucchelli et al. (1996)). Both LIFFE and MATIF inaugurated an ECU bond contract in 1990. LIFFE permitted the bonds of any EU government issuer, as well a number of supranationals, to be delivered into the contract. By contrast, the MATIF limited the deliverable paper to issues of France and the United Kingdom and certain supranationals, and precluded the delivery of Italian ECU bonds.*

In the event, given the considerable yield premium of Italian government bonds over French and UK government bonds denominated in ECU, the Italian government bonds proved the bonds consistently cheapest to deliver in London. As a result, the LIFFE ECU contract reflected not only the variation of ECU long-term interest rates, but also the volatility of the credit spread between single-A-rated Italian debt and triple-A-rated French government debt. For most portfolios of ECU bonds, or for most underwriters of ECU bonds, the Italian volatility in the LIFFE contract made it an inferior hedge. Partly as a result, the Paris contract stole the march over the London contract. Eventually LIFFE changed the rules to preclude the delivery of Italian paper, but by then liquidity had tipped to the Paris contract. The lesson drawn in London is that an excessively inclusive collection of credit risk in a futures contract, permitting the delivery of a number of issuers' bonds, can turn that contract into a loser (see Bloem (1996)).
\end{abstract}

* Gerard Pfauwadel, President of MATIF, told Reuters on 15th February 1991, the day that a UK ECU bond was admitted into the MATIF ECU bond pool: "Les conditions de signature de l'Etat italien font qu[e,] à mettre la ligne 2000 de l'Italie, on risquait de transformer notre contrat, qui porte tout de même sur un gisement de trois milliards d'OAT, en un contrat portant seulement sur un milliard d'écus italiens parce que la construction du notionnel fait que le prix du marché se fait sur l'emprunt le moins cher à livrer. Ces conditions techniques dans cette phase initiale de construction du marché font qu'il aurait été très dangereux de prendre un gisement trop étroit".

Last December the financial futures exchange in Paris published a report on plans to switch its futures contracts to the euro (see MATIF (1996)). ${ }^{12}$ The working group entertained two scenarios: one in which the current long-term contract on French government securities in francs becomes a contract on euro-denominated French government securities, and another scenario in which it becomes a contract on euro-denominated bonds of a number of euro-area governments. The report held that a "single yield curve", for at least a small group of European governments, was a necessary condition for a contract into which bonds of more than one issuer could be delivered. On the above

12 LIFFE is keeping all options open. See Gregorio (1996), p. 9. 
evidence, financial markets have come very close to trading the French, Dutch and German government bonds on a single yield curve.

Somewhere down the road, prospective interest savings through higher liquidity might encourage cooperative debt management by national treasuries. Governments need not hold joint auctions; they could simply match each other's coupons and maturities, in effect "reopening" each other's issues. The potential benefit of such an approach is evident in Table 9, in which the value of transactions in a European government bond market compares favourably with that in Japan and falls not far short of that of the United States.

\subsubsection{Liquidity and cooperative debt management: the evidence to date}

The prospect of European treasuries cooperating in debt management may well seem farfetched. After all, representatives of the German Federal Government, which has had to bail out ailing Länder (including Bremen and Saarland), worked for the "no bailout" provision in the Maastricht Treaty to reinforce market discipline on European governments. Any mixing of governmental approaches to the market might seem to raise the (moral hazard) risk that one government would support the other. Cooperation could lead to, or be seen to lead to, co-responsibility. Nevertheless, the brief history of the choice as to whether to redenominate government debt into euros at the first opportunity, now planned for early 1999, points to the power of liquidity to shape a common policy.

EU members agreed in Madrid in December 1995 that at the margin new public debt issues should be denominated in euros from the inception of the euro. The intention was to contribute to the euro's reaching a critical mass of transactions, including interbank transactions as well as these public debt transactions, so that private sector parties would opt to use the euro before its use becomes mandatory (some three years later). Subsequently, the French Treasury indicated that it would convert the entire stock of its debt from French francs to euros on day one, creating a whole yield curve in euros. In so doing, the Treasury drew attention to its book-entry ("dematerialised") system, which would make such a debt conversion more feasible. The Belgian Government has followed suit, announcing that it would convert most of its debt into euros, leaving unconverted only some notes in Belgian francs held mostly by households. The Dutch Finance Ministry has stated that the prospect for liquidity of the guilder market will figure importantly in its decision whether to redenominate. ${ }^{13}$

Early indications from the German Finance Ministry suggested that there would be no conversion of existing German debt. Yet strong and apparently successful arguments were subsequently advanced by German banks against such a policy. ${ }^{14}$ Essentially, the German banks

13 See Scobie (1997), p. 74.

14 The Working Group on the Gilt Market after EMU recommended the "complete and simultaneous redenomination of existing gilts from sterling into euro by law ... early in 1999, if the United Kingdom joins EMU at the outset or as soon as possible after it joins if it participates at a later date" (see Bank of England (1996), p. 34). 
argued that new issues of German bonds denominated in euros would have to yield 10-15 basis points more if the stock of German government debt were not converted into euros. Such a difference between the mark stock and the euro debt at the margin would probably be sufficient to interfere with auction strategies, cash/futures arbitrage and cash/cash yield curve positioning. In addition, Frankfurt stood to lose out to Paris as a financial centre were a large mass of French bonds deliverable into a euro contract there, while only brand-new issues were deliverable in Frankfurt. Note that the first argument could be made in the absence of any competitive threat. The German Government is now expected to redenominate its Bunds (although not the no-longer issued Treuhand bonds which financed reunification with eastern Germany). Without ignoring the competitive tensions sometimes dubbed the "race to benchmark status" — one should recognise that the liquidity argument has already brought two finance ministries to the same decision on the first important policy question regarding debt management in the single currency area.

Many challenges remain to integrating government bond markets in the euro area. Market conventions (such as interest day counts) and the organisation of the primary and secondary markets still vary from one market to another. ${ }^{15}$ There may be a prisoners' dilemma here, with major governments tempted by the prospect of achieving benchmark status on their own terms rather than cooperating to maximise liquidity (see Keating (1996)). The liquidity argument could give impetus to the difficult process of harmonising differences.

\subsubsection{Re-rating high-debt European sovereigns: lessons from Canada?}

How should the bonds of the more indebted European governments trade after the introduction of a single currency? The rating agencies have adopted different approaches to this question, but the remarkable outcome is that ratings judgements are closer together under the scenario of monetary union than they are now (see Box 2 opposite). For the most creditworthy governments, no change in their ratings is foreseen; for the rest, their ratings are foreseen at the double-A level.

The question may be interpreted as turning on the importance of the "printing press" as the last-ditch mode of debt payment. Governments have been granting rather more independence to central banks, so this option has not been gaining plausibility. A central bank can, however, help its government by increasing the duration of its portfolio of government debt, without running the printing press. Some would say only that with monetary union the probability of one kind of bailout — the central bank buying government debt under duress — would diminish while the probability of another class of bailouts involving European-wide institutions would rise.

15 The draft paper of the Consultative group on the impact of the introduction of the euro on capital markets (see European Commission (1997)) notes that the French and German Governments appear to be considering different modes of redenomination and cites the difficulties and costs resulting from the difference. The draft paper also discusses differences in day counts, coupon frequency, business days and settlement lags. See also Davies (1996). 


\section{Monetary union and sovereign ratings}

Over the years the major rating agencies have approached country (or transfer) risk in a fairly similar fashion. They assign a ceiling to the foreign currency ratings of all the borrowers in a country which reflects the possible unavailability of foreign exchange, even in cases in which the underlying debtor has ample domestic currency to service its debt and the currency is fully convertible. Until Moody's recent rating of Panama, this foreign-currency debt ceiling was also the foreign debt rating of the central government, and was thus often known as the sovereign ceiling. The rating agencies have in addition assigned ratings to the central government's domestic debt. These ratings have tended to be higher than the corresponding foreign currency ratings, particularly for Standard \& Poor's and IBCA, on the grounds that the national central bank would help prevent a default in domestic currency or, more generally, that the government's tax base in domestic currency made default less likely.

Generally, the rating agencies are treating EMU as a likely event, and they have already begun to factor the prospect into the sovereign ratings of potential members. Of course, the fiscal discipline of the Maastricht criteria means that a prospective participant in monetary union can hope to see its ratings improve, as with Moody's recent upgrade of Ireland. (Reuss (1996) shows, however, that of the nine countries with lower than AAA ratings in Table 10, five have seen their Standard \& Poor's foreign currency ratings downgraded since their initial ratings, and only two have seen them upgraded.) But the prospect of EMU poses two other questions for the major rating agencies: what should be the sovereign ceiling for the euro area, and how should the foreign currency and domestic currency debt ratings, where they differ, be united?

Moody's (1997) recently agreed with the views of Standard \& Poor's (see Beers (1996)) and IBCA (1996) as outlined last year, that the risk of a transfer problem affecting foreign currency issues by borrowers in the euro area should be negligible. That is, these agencies treat as practically zero the likelihood that a government or other obligor in the euro area would have euros but would be unable to convert these into the dollars or Swiss francs needed to service its debt. This conclusion would apply more or less regardless of the participants in monetary union because the aggregated external creditor status of Europe would be very strong in any case. Moody's and Standard \& Poor's, however, approached differently the question of what to do with the split between their foreign currency rating and their domestic currency rating for some European governments.

Moody's argued that the euro would effectively become the domestic currency of any member country, just as the dollar is the domestic currency of Massachusetts. Therefore, the rating of a government in the euro area should correspond to its (in many cases higher) current domestic currency rating. By contrast, Standard \& Poor's argued that under EMU central governments lose their privileged position and that therefore it makes sense to unify the ratings of individual sovereigns on the (in many cases lower) current foreign currency ratings.

The agencies' divergent views seem to be primarily based on a differing weighting of the value of a national central bank to the creditworthiness of the central government. Standard \& Poor's believes that the national central bank would help its government to avoid default. Moody's questions this "printing press" view and says that most governments have already abolished this policy option by giving autonomy to their central banks. Thus, market discipline, including the prospect of capital flight, already makes it almost impossible for a central bank to help its government even in extremis. As a result, Moody's has made less of the distinction between foreign currency and domestic currency ratings and has lower domestic debt ratings. The difference between the current domestic currency rating for Italy, rated AAA by Standard \& Poor's and Aa3 by Moody's, illustrates this point. It might be noted that the yields on Italian interest rate swaps for prime (AA) names have often been below those for the Italian Treasury (see Graph 3), suggesting that financial markets have seen more risk in the Treasury's lira debt than has Standard \& Poor's (see Banca d'Italia (1995), pp. 125-126 and Favero et al. (1996)).

These differing views of the rating agencies led to speculation that there might be wide disparities (and resulting uncertainty) between sovereign ratings under EMU. In practice, however, Standard \& Poor's foreign currency rating for Italy (AA) is just a notch higher than the Aa3 domestic rating of Moody's. Thus, owing to Standard \& Poor's more buoyant current ratings of domestic debt, the different approaches to unifying the government ratings will not result in large differences under the euro (see Table 10). Although Standard \& Poor's has been described as rating sovereigns marginally higher than Moody's (see Cantor and Packer (1996), p. 39), at this stage Standard \& Poor's indicated EMU ratings are lower than those of Moody's for Finland, Greece, Ireland and Portugal.

Despite the different starting-points of the two ratings agencies, and their different analysis, in the end their ratings would thus not be very different. Moody's could portray its decision to treat the euro as a domestic currency as more logical than Standard \& Poor's treatment. In addition, it is easier for the affected governments to accept Moody's planned abolition of their foreign currency ceiling, since only upgrades are implied, than it is for them to accept Standard \& Poor's planned downgradings of domestic debt. Standard \& Poor's, for its part, could back off somewhat from its domestic currency ratings. 
It may be informative to consult the experience of Canada, a federation of provinces, for guidance as to how European government debt might be treated under the single currency (see Brookes (1997), Bulchandani (1996), Clarke and Parry (1996), Islam et al. (1996), Lipsky et al. (1996), SBC Warburg (1996) and Serfaty (1996), but also Fox (1996) and Keating (1996)). In the domestic Canadian bond market, the Federal Government represents the top-rated benchmark and the cost of provincial debt bears a close relation to provincial credit ratings, with Quebec yielding a premium that may reflect a risk of exit from the federation (see Graph 4). To compare the situation in Canada with that in Europe requires a common measure of spreads across different markets, and the interest rate swap yield in Canadian dollars and in European currencies can be taken as a common (double-A-rated) reference point. When the spreads of the Canadian provinces and European governments (see Graph 3) are plotted against their respective ratings, it appears that these various bond markets price lower ratings in a reasonably similar fashion (see Graph 5). ${ }^{16}$

But a juxtaposition of the Canadian and European observations raises a question regarding the consistency of the determinants of the ratings themselves. When the Canadian ratings are plotted against the debt burdens of the Canadian provinces, the ratings all line up; when the prospective ratings of the European governments under the assumption of monetary union are plotted against current debt burdens, the ratings do not line up so well. ${ }^{17}$ How good an analogy does the Canadian bond market provide for European debt markets under monetary union? ${ }^{18}$ Those who have looked most carefully at such questions have identified three critical dimensions that affect the capacity of a government to carry higher debt burdens: whether household and corporate taxpayers can readily move to avoid tax rises; the degree of federal support in the event of difficulties in debt servicing; and the capacity of the political system to produce coherent governments capable of making difficult choices (see Eichengreen and von Hagen (1995)). On the first dimension, European governments may have scope to carry heavier debt burdens because labour (and capital?) is less mobile than in Canada. On the second dimension, Canada's federal redistribution and constructive

16 While market pricing qualitatively corresponds to the credit rating, the triple-B province pays a smaller premium than most similarly rated private borrowers. Some observers interpret the relative flatness of the relationship to suggest that the market attaches more weight to the possibility of a federal bailout than do the rating agencies.

17 It is easy to draw this analogy inappropriately by neglecting differences in fiscal structures. "A 55\% debt to GDP (gross domestic product) ratio appears to define the limit at which Canadian provinces can maintain investment grade status. What's going to make it possible for European governments to maintain good credit ratings with debt ratios significantly higher?" Bernard Connolly, addressing a conference in London and quoted in "EMU said to mean higher inflation, weaker bonds", Reuters, 25th February 1997. Moody's (1997, p. 5): "... a statistical comparison between the debt burdens of EMU entrants and subnational units in federal systems would not be completely appropriate because EMU countries should be able to service higher debt loads than individual American states or Canadian provinces".

18 The Canadian parallel has the advantage that there is no federal tax exemption for provincial debt interest receipts, as there is in the United States. In the latter case, a combination of federal tax exemption with state tax exemptions for in-state municipal bond interest has produced an extremely segmented and illiquid market. For the comparison between US states and European governments, see Goodhart (1997). 
ambiguity must be contrasted with the European Union's limited budget and Maastricht's clear statement that there would be no Community liability for, or assumption of, the debts of any troubled government. On the third dimension, Canadian parliamentary democracy, like that of the United Kingdom, produces more coherent governments than the electoral systems of some EU countries. The Canadian provinces thus provide a useful if imperfect analogy for European governments under the single market, with two of the three arguments above implying that debt levels should be of more import than in Canada.

\subsection{Implications}

The greater depth, breadth and liquidity of the euro bond market carry implications both internal to the euro area and external to it. Internally, one should expect the portfolios of institutional investors gradually to lose their bias towards home-country assets. As this diversification occurs, one should expect that the lower cost and the greater benefit of using the bond market should move the boundary between the banking market and the securities market in favour of securities away from loans. Thus the shift by banks from acquiring and holding assets to underwriting and distributing paper should accelerate, with different implications for banks with strengths in these two aspects of the business. Repurchase markets can also be expected to grow, to some extent at the expense of bank deposits.

Internationally, the euro bond market can be expected to be a more attractive place for asset managers, both official and private, in which to invest. Many analysts stop here and draw the conclusion that the euro could be secularly strong, as it benefits from portfolio reallocations at the expense of the dollar. But debtors, both companies and governments, outside the euro area can also be expected to find the euro bond market a more attractive market into which to issue. Thus a larger, broader, deeper and more liquid bond market in Europe does not necessarily imply that the value of the euro will benefit from net portfolio shifts.

\subsubsection{Internal implications}

\subsubsection{The gradual process of portfolio diversification}

A single reference yield curve for the pricing of private credit risks, in conjunction, perhaps, with a government benchmark yield curve, is a necessary but not sufficient condition for an integrated bond market. As long as the portfolios of insurance companies, pension funds and mutual funds show a strong bias towards home-country issuers, then integration will remain partial. ${ }^{19}$ Many

19 OECD (1996a), p. 16, shows pension fund holdings of foreign assets in Europe to be bi-modal, with funds in Belgium, Ireland and the United Kingdom having $30 \%$ or more of their portfolios invested in foreign assets, compared with less than $10 \%$ for funds in Denmark, France, Germany, Italy, Portugal, Spain and Sweden. The Netherlands, at 17\%, is in between. Ibid, p. 22, shows life insurers in Germany with 1\% of their assets in foreign securities in 1991 and those in the United Kingdom with 14\% in 1994. 
such portfolios have currency matching requirements (see OECD (1996a), pp. 5-17) intended to limit the risk inherent in having obligations to policyholders or fund claimants denominated in one currency and assets in another. Some of these requirements are written in such a fashion that monetary union will automatically permit investment by the affected institutional investors in the euro debt of issuers of a different nationality. Other such requirements confound the nationality of issuer with the currency denomination of the bond and would continue to be binding after EMU. Pressure to remove such portfolio restrictions can be expected, but the European Commission's proposed Pension Funds Directive, which would have limited regulatory restrictions requiring investment in national assets, has not yet been adopted (see OECD (1996b), p. 19). The process of portfolio diversification within the euro area will not, in these circumstances, be an instantaneous process like the development of a single private yield curve in euros. "Old habits and preference for national debt die hard" (see Bloem (1996)).

\subsubsection{Growth of securities markets in the euro area}

Bigger and better money and bond markets could lead to a migration of assets from banks' balance sheets through the commercial paper and corporate bond market to the balance sheets of insurance companies, mutual funds and pension funds. But a widespread misunderstanding of the process of securitisation in the United States risks a significant overestimate of its potential in Europe. Much of what goes under the heading of securitisation in the United States is the bundling of home mortgages into securities, which has depended on government and quasi-government guarantees to remove the idiosyncratic credit risk from the underlying assets. To be sure, these guarantees have also induced technical developments in the bundling of assets to back bonds and these techniques have been applied as well to assets not benefiting from such guarantees, including large mortgages, credit card receivables, automobile loans, and even boat loans and aircraft and equipment leases. But such techniques are only now finding application in Europe (see Jeanneau (1996)). Here we concentrate on the prospects for the growth of the commercial paper corporate bond markets in Europe.

After the euro arrives, corporate treasurers in the euro area would make a different calculation of costs and benefits in choosing whether to issue commercial paper and bonds or to borrow from a bank. The cost of a new bond issue would be lower because of more competitive underwriting in a market no longer segmented by currency. Moreover, to the extent that the government bond market in Europe becomes more liquid, the cost to underwriters of hedging a new issue, through taking a short position in government bonds in the cash or futures market, would decline and this saving would also be expected to pass through to the borrower. Other costs, such as the cost of obtaining a credit rating and the cost of marketing to a given class of investors, would not rise with the euro. Moreover, with time, the benefits of issuing its own commercial paper or bonds would rise for a corporation in the euro area. That is because the range and size of the investment portfolios to which the securities could be marketed would also rise as euro-area asset managers 
looked beyond national boundaries to improve their performance. Under these circumstances a lower yield could be required to place paper and bonds of a given quality.

From the perspective of asset managers in Europe, a greater capacity to analyse credit risk and a greater tolerance for credit risk could be expected to result from the euro's elimination of currency risk. As things stand, the manager of a multicurrency bond portfolio faces a hierarchy of choice, in which the most important choice is across countries, the second-tier choice is duration, and the last choice is credit risk. As matters stand, this last choice is a very safe one: "Almost $50 \%$ of non-sovereign issuance is AAA in the European currencies segments" of the eurobond market (see Karsenti (1996), section 4.4). The elimination of the currency choice within Europe can be expected to result in greater attention to the duration and credit choices and, in the search for higher yields, a greater tolerance of risk in both dimensions.

How far could this improved calculus alter the corporate securities market in Europe? The potential for assets to be stripped out of the banking system is illustrated by the growth of the original-issue junk bond and commercial paper markets in the United States. From a base near zero in the early 1980s, outstanding bonds of non-investment-grade firms rose to over \$200 billion in 1996 (see Fridson and Garman (1996), p. 28), equivalent to about a quarter of outstanding corporate bank loans. In addition, outstanding commercial paper of mostly well-rated non-financial firms approached \$200 billion in 1996, well beyond the levels reached in the late-blooming European paper markets (see Alworth and Borio (1993)). ${ }^{20}$ Following these precedents, security markets could place at risk one-third of European banks' corporate loans.

If the euro can be expected to accelerate the expansion of securities at the expense of bank loans, it can also be expected to accelerate competition from securities markets on the deposit side. The euro repo market, essentially a money market instrument collateralised against government bonds, would compete with bank deposits for short-term funds. In the United States, mutual funds, state and local governments (and their pension funds), foreign investors, pension funds and insurance companies are the largest providers of funds under repo arrangements. In contrast, these kinds of investors in Europe would currently hold bank deposits. ${ }^{21}$ While banks themselves are the largest takers of funds in the US repo market, followed by securities dealers, these collateralised instruments may compete directly for funds with high-quality European banks that are now able to offer low yields on their low-risk liabilities.

20 See Table L.102 in Board of Governors of the Federal Reserve System, Flow of funds accounts of the United States, Flows and outstandings, Third quarter 1996, 11th December 1996, p. 63. Overall, these accounts place the bond debt of the US non-farm non-financial corporate sector at $\$ 1.4$ trillion and commercial paper debt at $\$ 0.2$ trillion, against bank debt of $\$ 0.6$ trillion. The inclusion of offshore corporate loans brings the corporate loan total closer to $\$ 0.8$ trillion (see McCauley and Seth (1992)). The one-third figure following in the text ((junk + commercial paper)/(junk + commercial paper + bank loans)) is apposite under the conservative assumption that all the European firms that could obtain investment grade ratings have already effectively ceased borrowing long-term, fixed rate funds from banks.

21 See Board of Governors of the Federal Reserve System, op. cit., p. 84. 
In Europe, repurchase markets are developing rapidly (see BIS (1996a), p. 74 and BIS (1996c), pp. 20-24). Once the ECB starts operating in the repo market, with an undifferentiated range of government paper accepted collateral, then the euro can be expected to accelerate the growth of the repo markets in Europe.

In summary, the stimulus given to the European money and bond markets by the euro can be expected to make commercial papers and bonds more serious competitors for bank loans. More European firms will find it rewarding to issue paper and bonds, and the euro repo market will offer a deep and high-quality alternative to bank deposits.

\subsubsection{International implications: investment and borrowing in the euro}

Many analysts foresee that international portfolio shifts into an increasingly broad, deep and more liquid euro market have the potential to make the euro a strong currency. On the basis of similar portfolio reasoning, however, we view this presumption as not a safe one, because the euro would also be a more attractive currency in which to borrow.

Greater liquidity and depth could increase the international demand for bonds denominated in euros relative to the total demand for bonds in the constituent currencies. In considering the potential for shifts by private portfolio managers into the euro, a difficult question arises as to whether interest rates in a large euro bond market might show a smaller correlation with US bond yields than current European government bond rates. This is an interesting question because private portfolio managers would find the euro bond market particularly attractive if it offered diversification benefits superior to anything available in the constituent bond markets. Large size and diverse investors could provide ballast to a European bond market subject to spillovers from New York. However, it is notable that the trend towards higher correlations across European bond markets in recent years has not to date brought any diminution of the correlation between the German and US markets.

The scope for a potential reallocation of private portfolios from the dollar to the euro is necessarily extremely conjectural. One starting-point is the shares across G-10 currencies of GDP, trade and international assets, including both international bank deposits and international bonds. The G-10 members of the European Union produce about one-third of G-10 output and would show a slightly smaller share of international trade (net of their intra-EU trade). After a similar consolidation, however, the share of international assets denominated in euros would be only about one-eighth. For the euro share to match the output and trade share of G-10 members of the European Union would require a shift of some $\$ 0.7$ trillion (see McCauley (1997)). This figure should not be taken too seriously. Nevertheless, it serves to make an important point: namely, that private portfolio shifts could prove to be much larger than any possible official reserve shifts. 
As well as having strong attractions for asset managers, a more integrated bond market in Europe would also attract debt managers in the steady state. The development of a broad and deep euro bond market could potentially affect debt management more strongly than asset management, and the greater supply of euro-denominated assets could place downward pressure on the euro.

It may seem strange that something as welcome as the development of broad, deep and liquid markets could weaken the currency concerned, but portfolio theory holds that the shift of funding from one currency to another will result in some combination of a higher interest rate and a lower exchange rate for the currency experiencing the increased supply. For instance, were Thailand to issue new DM securities and use the proceeds to buy in all its dollar debt, private investors would need to be induced to hold more marks and fewer dollar assets. Depending on the size of the operation, one might expect some combination of higher DM interest rates and a lower mark in order to make the investors willing to hold the new proportion of assets supplied. The flow conception of exchange rate determination agrees with the result: as the Thais exchanged the marks raised for dollars with which to buy their outstanding debts, demand for the dollar would rise.

The current choice of currency for large issues for global debt managers and the current financing habits of emerging economies make the prospect of heavier use of the euro by debt managers plausible. As things stand, international bond issuers favour the dollar for large deals (see Table 11). A plausible interpretation is that US Treasury bond benchmarks in the cash market are larger, the bond futures markets serving the dollar bond markets are more liquid and the ultimate bond buyers are bigger. If an underwriter of a large bond in euros could more easily hedge against movements in the underlying euro yields, issuing costs might fall, eliminating this bias. The likely result would be more issuance in euros.

Faced with a broader, deeper and more liquid bond market in Europe, debt managers outside Europe could be interested in increasing the proportion of their debt denominated in euros. The estimated currency composition of the international debts of countries in Asia and Latin America (see Table 12) shows a very low share of European currencies. ${ }^{22}$ Even if the euro does not displace the dollar or, in Asia, the yen as a reserve currency, there is great scope for additional borrowing in euros to cover existing exposures. Currently, the weight placed on European currencies in the reserves of non-industrial countries is noticeably heavier than that in the debts of those countries.

It is possible that the attraction of a larger supply of euro-denominated assets, which in a portfolio balance framework would push down the value of the euro, could outweigh the attraction of a larger demand, which would push it up. Even if the demand shift is foreseen to be larger or faster, it should be recognised that the international bond market regularly shifts the composition of new

22 Contrast Benassy-Quéré (1996) which takes World Bank-reported debt as representative. 
offerings towards the strengthening currency. ${ }^{23}$ At any rate, one should not attempt to calculate the effects of the greater attraction of the euro for official and private asset managers without considering that it might hold a similar attraction for debt managers.

\section{The euro and the European banking system}

The successful introduction of a single currency will have direct effects on individual financial institutions. In particular, in the transition it seems certain to raise some costs, cut some revenues and increase uncertainty in some respects. It is also certain to alter the macroeconomic environment in which financial institutions operate. What is much more problematical is whether the introduction of the euro will catalyse a significant increase in international competition between financial institutions. On this issue, views differ widely and predictions are highly uncertain. ${ }^{24}$

\subsection{The transition costs of monetary union}

What is clear is that banks will have to bear increased costs during the transition. Customers will seek advice on EMU matters; computer systems have to be altered; stationery and forms must be reprinted; and personnel need to be trained. ${ }^{25}$ Moreover these costs, especially for computer systems, are liable to increase dramatically for those institutions which choose to delay their preparations in light of perceived uncertainties about the introduction of the single currency. Influenced as well by the need to deal with the "year 2000" problem, the salaries of information technology personnel have already begun to rise significantly. Indeed, given shortages in this area and the number of financial firms that have not yet commenced their preparations, ${ }^{26}$ some commentators have even started to question whether current deadlines for EMU are technically feasible. ${ }^{27}$

23 This shift (which reflects more than valuation effects) is a leitmotif of the BIS International banking and financial market developments. See in particular BIS (1997) and BIS (1996c).

24 Among those expecting profound changes are Standard \& Poor's (see Bugie (1996)). Among those who expect a much smaller impact are Salomon Brothers (see Salomon Brothers (1996)).

25 The Banking Federation of the European Union published the results of a survey of members in March 1995. Assuming a single date of conversion for all forms of business in all EU countries, the costs of conversion were estimated at between ECU 8 and 10 billion. National estimates of conversion costs are broadly consistent. The actual costs of conversion are likely to be significantly higher (the British Bankers' Association estimates up to 50\%) given the necessity for banks to keep accounts in both national currencies and the euro during the period from January 1999 to 2002. This implies added costs of about $1-1.5 \%$ of total revenues per year over a three to four-year period. See Salomon Brothers (1996), p. 5.

26 A survey reported in the Financial Times of 5th February 1997 ("European monetary union: impact on IT systems" by Nicholas Denton), indicated that $91 \%$ of European banks polled were confident that they would be ready for the introduction of the euro but only $15 \%$ of the same banks had allocated a budget for this objective.

27 See Congdon (1996). 
After the introduction of the single currency, banks will have extra note-handling costs and will lose revenues in other ways. An obvious point is that trading revenues from foreign exchange transactions between currencies subsumed into the euro will disappear. On the basis of turnover data collected by 26 central banks for the Central Bank Survey of Foreign Exchange and Derivatives Market Activity 1995, ${ }^{28}$ Salomon Brothers (1996, p. 9) estimates that the net revenues derived from foreign exchange trading might fall by up to $10 \%$, although this would imply only about a $1 \%$ decline in total revenues. Receipts from intra-European funds transfers might also be expected to decline, as would fees from the exchange of travellers' cheques and banknotes. Revenues from bond trading across European currencies might also be reduced, given that changes in perceptions about credit risk are less volatile than expectations about exchange rate changes. Bond trading is also likely to migrate to larger centres, which could have significant effects on financial institutions based in smaller centres. It is also yet to be determined whether financial institutions within EMU will be subject to reserve requirements. If they are, and these reserves are not interest-bearing, this will be a further charge for banks to bear even if some part of it might well be passed on to their customers. ${ }^{29}$ Finally, there may be certain national conventions that are currently profitable for banks but which might disappear under EMU; for example, "sight deposits" in France still do not pay interest even though ECU "sight deposits" do.

The introduction of the euro will also raise other uncertainties for banks. First, the replacement of national currencies with the euro could call into question the legal validity of some outstanding contracts. It cannot be ruled out that counterparties (particularly non-European) on the losing end of a contract will seek to avoid that loss by having recourse to non-European courts. ${ }^{30} \mathrm{~A}$ closely related possibility is that borrowers with high, long-term, fixed rate obligations in national currencies will litigate for the right to renegotiate at lower euro rates. ${ }^{31}$ The final effects of this on banks individually and collectively is not obvious. Second, during the whole period prior to stage three of EMU, shocks could occur which might call the commitment of individual countries to participation into question, complicating advance planning by banks.

A last consideration is that many of the sovereign participants in EMU should eventually gain the benefits of faster growth, lower inflation and lower market volatility that EMU is expected to provide. However, for banks this will be a mixed blessing. Banks will share in the benefits of faster growth, but lower inflation could well lead to a reduction in interest rate spreads. Lower inflation may also (over the medium term) exacerbate problem loans associated with current low property prices, although (over the longer term) it might make a repetition of such exposures less likely. As for

28 See BIS (1996b), p. 96.

29 For a fuller discussion of this potentially important issue, see Levitt (1995).

30 See Livingston and Hutchings (1997), p. 63 and International Law Association (1996). See also Section 2.1 above.

31 See Levitt (1995). Levitt notes that litigation in different national jurisdictions might result in different rulings. EU legislation might be called for but, of course, it would have no force outside the European Union. 
volatility in financial markets, banks will face less market risk themselves but they will also lose the revenues derived from helping their clients cope with market risk. In a more stable environment, credit risk should also be easier to evaluate and should generally be lower. In contrast, under EMU the likelihood of bailouts of national (non-bank) firms by national governments may be significantly reduced, which would imply higher levels of credit risk in some cases.

\subsection{The euro and increased competition in banking}

Rating agencies do seem to feel that EMU will increase competitive pressures between financial institutions. ${ }^{32}$ Indeed, this must happen if the very significant gains for consumers, foretold in the Price Waterhouse report of 1988, are to be realised. However, in light of the relatively limited competitive response to date, this conclusion might seem questionable unless one were to ascribe an important catalytic role to the introduction of the euro itself. A number of arguments have been made in this regard, though they vary widely in their persuasiveness and no single argument seems to us to be totally persuasive. The euro is projected variously to cause bank customers, regulators and legislators, and financial institutions themselves to alter their behaviour.

Perhaps the loftiest of these arguments has to do with the attitude of bank customers. Recall that the introduction of the euro is intended to serve as a powerful political symbol uniting Europeans and reducing the importance of national differences. Would it not then be expected to play the same role in the financial sector? Indeed, Johnson (1996, p. 51) goes even further to argue that "It is intuitively obvious that the existence of separate currencies must divide the market in money even more than those in other goods and services". However, it remains to be seen how long it might take for a Yorkshire farmer to view German, French and UK banks with equanimity.

Another argument pertaining to customer attitudes has been put forward by the Association Cambiste Internationale (1995, p. 24). It feels that "the single currency, by eliminating foreign exchange rate risk and converging interest rates .... will result in a greater willingness on the part of customers to look outside national borders for financial services". While more prosaic than the first argument, it is also more compelling. Multinational firms may consolidate their European treasury operations and with them their banking relationships. Increased transparency and increased comparability between fee structures and rates offered by banks in different national jurisdictions should also help to promote convergence. This might apply particularly in border regions, but it could apply much more broadly given the growing influence of electronic banking (often being introduced by firms unencumbered by traditional branches) and the use of credit scoring techniques. The essence of both is that physical proximity to customers is not required. An important counter-argument, which

32 EMU "will be negative or neutral for European banks" (see IBCA (1996)); "the profound changes that a successful EMU will bring to the financial services sector will pressure the competitive position and earnings of many banks" (see Bugie (1996)). 
may have some force during the transition period at least, is that smaller customers may choose to rely still more heavily on their traditional bankers for advice in a period of change.

It has been further contended that separate currencies also serve to segment the market for bank credit in Europe. However, some limited evidence suggests that separate currencies may not have a great impact on borrowers' preferences. As indicated in Table 13, the effect of currency on the choice of syndicated loan arrangers stands out less than does the home-country relationship. This finding contrasts with that discussed in Section 2 above, where currency plays a more important role in the choice of bond underwriters.

Another argument having to do with transparency notes that regulatory and other such differences which segregate national markets will be put into higher profile in a single currency area; the opt-out clause in the Second Banking Directive (for "the general good") might be particularly vulnerable in this regard. Pressures on regulators and legislators for further change might then be expected to arise from those judging themselves to be disadvantaged. Calls for effective "national treatment" might be expected to lead to pressure for "reciprocal" treatment which could only be fully satisfied through complete harmonisation.

If and when competition does begin to increase significantly, a further and important dynamic process might be generated. With profits under pressure as a result, and some banks' credit ratings potentially declining even below those of some of their customers, the process of disintermediation might be expected to accelerate significantly. In fact, this is broadly what happened in the United States in the early 1980s in the wake of the debt crisis. And as profits decline, there would likely be a further intensification of the attacks on those market practices deemed to give some institutions an unfair competitive advantage. In sum, a number of interacting factors could (and this is a possibility rather than a forecast) sweep away remaining barriers to international competition in the banking area while at the same time putting all banks under increasing pressure from securities markets.

A single currency could also change the behaviour of financial institutions, inducing them to internationalise both their corporate and retail businesses. The need to change internal computer and information systems could (indeed should) prompt a strategic rethinking of the business functions those systems are designed to support. ${ }^{33}$ Turning first to corporate lending, it must be noted at once that this is not at present a very profitable business in continental Europe. ${ }^{34}$ This in itself could inhibit expanded competition, as could concerns by lenders that most available foreign clients would be clients that no-one else wanted (the adverse selection problem). In contrast, it could also be

\footnotetext{
33 The likelihood of this approach being taken, in contrast to a minimalist solution, will depend on how much advance planning has been possible. Recent surveys assessing the degree of preparedness for EMU indicate that simple "coping" may be the order of the day for many financial institutions. See footnote 26.

34 See Gemini Consulting and EFMA (1993).
} 
argued that cross-border "cherry-picking" might become even more attractive given a single currency than it is today. ${ }^{35}$

It has also been contended that making medium-term loans in foreign currencies, using short-term domestic funding sources, exposes banks to special liquidity risks. ${ }^{36}$ This discouragement to cross-border lending will certainly disappear with the introduction of the euro, though the magnitude of the resulting effects remains to be determined. However, some guidance on this can be obtained by noting that lenders currently have the possibility, albeit at a cost, of obtaining the required foreign currency for a medium-term period using cross-currency basis swaps; the cost of such swaps (see Table 14) might be seen as a measure of how much different currencies segment the European lending market. In fact, two conclusions arise from Table 14. First, the cost of such swaps is modest, though not trivial. Second, segmentation seems to work to the advantage of banks in some countries more than others. In particular, bank lending in marks, guilders and French francs seems more protected by borrowing costs than does lending in the lira or Belgian franc.

Whether the introduction of the euro will induce banks to compete more vigorously for retail customers across international borders, ceteris paribus, is even more problematical. Hoschka (1993) and others have argued that foreign banks need some other competitive advantages to stimulate cross-border entry in European retail banking since they face such well-known disadvantages as "reputation" problems, a smaller transaction base, less experience with the local market and the potential costs of new branches. Could it then be argued in turn that the introduction of the euro might increase the likelihood of such competitive advantage? On the one hand, a consideration of Hoschka's individual arguments gives few grounds for believing that the introduction of the euro would have any more than a marginal influence. ${ }^{37}$ On the other hand, a single currency will simplify the accounting of cross-border activities and will allow banks more easily to distinguish those cross-border niche activities which are profitable from those which are not. Moreover, should new competitive opportunities open up in retail banking, because of other changes related to the euro, there is no reason to believe that the banks would be any less inclined to respond than is currently the case.

35 Citicorp in Germany has already had a significant degree of success in attracting the business of high-income investors away from German banks.

36 See McCauley (1984). The bank lending in a foreign currency is likely to have less well-diversified funding sources. In addition, it does not have access to its own central bank for foreign currency.

37 Hoschka's first point is that foreign banks may have an advantage from being able to follow domestic clients as their activities become increasingly international. The euro would certainly promote this, though the effects on corporate business would seem greater than the retail effects. A second potential source of firm-level advantage is "know-how" about new products. It is not obvious that the introduction of the euro would have much effect in this regard, and the same might be said about a third possibility mentioned by Hoschka: namely, that cross-border entry might be attracted by ologopolistic profits in domestic retail banking. A fourth possibility, that foreign banks might benefit from diversification of risk through cross-border retail activities, would seem more likely to be reduced than increased by the introduction of the euro. 


\subsection{The need for adjustment and potential difficulties}

The direct costs associated with the introduction of a single currency, and the associated increase in competition in the context of EMU, will put further pressure on bank profits and encourage adjustment of various sorts. The severity of that pressure will depend partly on the extent to which the introduction of the euro catalyses other changes and may well vary in intensity across countries. ${ }^{38}$ Whatever one believes in this particular regard, market sentiment is that the European banking industry will be radically transformed over the coming years. A 1993 survey ${ }^{39}$ of 65 bankers in 15 different countries foretold a collapse of profits in corporate banking and the survival of only 10 to 20 retail banks across Europe by the year $2005 . .^{40}$ It is worth considering briefly how banks might react to increased competitive pressures and some of the pitfalls along the way.

Within individual firms, competitive pressures could result in three sorts of efforts to increase profits. In the first place, there could be efforts to increase productivity and to cut costs. Tables 15-17 indicate that this process is not well advanced in Europe. In partial contrast, Gual and Neven (1993, p. 176) note that deregulation in European banking prior to 1990 did lead to some increases in productivity, but that the "rents" earned by workers were nevertheless generally well maintained. ${ }^{41}$ One particularly important problem in many European countries is the existence of labour legislation (or the general nature of existing contracts) which not only makes it difficult to lay off staff in general, but also makes it particularly difficult in the financial sector. ${ }^{42}$ Indeed, in some cases there are even significant impediments to relocations and other initiatives short of outright loss of employment. The high degree of unionisation, allied with strong state involvement in banking, also increases the likelihood of an associated politicisation of all measures designed to increase efficiency. All this having been said, the good news is that major efficiency gains are potentially still there to be achieved if these obstacles can be overcome.

A second possibility is that individual firms might be tempted to restore sinking profit margins by taking on more risk. This is not implausible. Indeed, the behaviour of US (and many

38 The banking systems of smaller countries might be thought particularly exposed. They tend to be more reliant on foreign exchange receipts from transactions in their own currencies, and are geographically closer to competing financial systems. In cases where the banking system also relies heavily on "core" deposits paying less than market rates, the implications would be still more serious. See Berlin and Mester (1996).

39 See Gemini Consulting and EFMA (1993).

40 It is not clear what the forecast was for retail banking in Germany, where there are currently thousands of mutual and cooperative banks. While independent and actively merging, these banks operate within the framework of national associations offering extremely sophisticated central services. In this respect, they already look much like large retail banks with many branches.

41 They also note (p. 179) that compensation in European banking continues to be substantially above economy-wide compensation.

42 For example, in France there are the constraints imposed by the decrees of 1936 and 1937. In Italy, Parliament recently passed a special law regarding the restructuring of the Banco di Napoli. Presumably, this reflected an assessment of the difficulties imposed by existing law. 
other) banks after the debt crisis of the early 1980s - behaviour which led successively to heavy investment in commercial property, leveraged buyouts, market trading and emerging market debt once again in the early 1990s - may well have been motivated by such considerations. Even if such a possibility were to be discounted, any significant increase in cross-border competition after the introduction of the euro will likely imply that many banks will be making credit evaluations of previously unfamiliar counterparties. Errors of judgement will be easier to make in such an environment.

A third and more positive possibility is that banks will turn to new products and lines of business to enhance returns. Indeed, this has already begun, with German banks in particular buying up UK firms with a view to increasing profits from investment banking. Should there be (as suggested in Section 2) a substantial increase in the issue of euro securities, European banks should be first in line to profit given the revealed preference of issuers to choose underwriters from the same currency area (see Section 2.2.2). However, following an investment banking strategy involves enormous infrastructure and staffing costs up front. As for other aspects of the investment banking business, it must be noted that global competition may be more fierce. For example, in 1996 five of the top ten firms doing cross-border mergers and acquisitions in Europe were US firms, and Goldmans for the first time did more business in France than did Lazard Frères. Asset management is another area where fee income seems likely to increase sharply on the basis of changing demographics and a potential substitution of private saving for state-sponsored schemes. Again, however, positioning has already begun and continental banks may expect strong competition from both UK and US financial firms.

Other opportunities at the inter-firm level will also be exploited to deal with competitive pressures. Mergers and acquisitions are one possibility, ${ }^{43}$ though such moves may also run into political resistance and labour legislation which limits the ability to gain the full benefits of either scope or scale. ${ }^{44}$ As indicated in Table 18 , not a great deal has happened in this respect in continental Europe to date. Another possible strategy will be the pursuit of cross-border alliances, which will allow firms to supply special services over a much wider area than would have been possible otherwise. In itself, however, such a strategy of alliances among existing market participants does not materially address the underlying problem for the industry as a whole: namely, that the rate of return on capital is likely to remain too low.

43 It is not easy to evaluate the extent to which M\&As do add value. Borio and Tsatsaronis (1996) look at movements in relevant share prices (in major industrial countries) just before and after announcements of M\&As in the finance area. The evidence for a significant increase in "expected" value is not strong. See also BIS (1996a).

44 In the United States, the biggest gains have generally come from consolidating back and middle-office functions. A new development in Canada has been the spinning-off of such functions and their merger into a single and more efficient company owned by a number of banks. 
The final possibility is that some of the capital currently in the financial services industry in Europe will be withdrawn and/or consolidated in some way. Hopefully, this will happen in an incremental and non-disruptive fashion as smaller firms are closed or taken over. Yet, as the process of consolidation continues, and remaining firms become larger and larger, the likelihood of a disruptive failure could also increase (see Schoenmaker (1995)). This likelihood may also be further increased if two recent trends continue. First, given the high costs of the information technology which will be needed to ensure survival (at least for a time) in such an environment, fixed costs will rise relative to variable costs. This implies that, in the later stages of any restructuring process, it may make sense for some firms to continue to operate at a loss for an extended period of time. Second, if the recent trend towards using "branding" as a competitive tool continues, the purpose of which is to ensure that all parts of a business are associated with the brand name, it may become harder to close down unprofitable parts of a business than in the past. Should the current resistance of national governments to closures also be maintained, ongoing competition from non-viable banks could continue to threaten the prospects of other banks and the health of the financial system more broadly.

\subsection{Implications}

The possibility of intensified competition and the need for restructuring within European financial markets highlight a number of issues for public policy. Prudence of course demands that these be addressed in the spirit of "planning for the worst", even while anticipating the best. Within Europe itself, the first issue has to do with the incentive structure for sound banking provided by the authorities. Closely related is the issue of preventing problems from occurring and managing them when they do. A third issue is the implications of a single currency for the transmission mechanism of monetary policy and related implications for financial stability. Given the importance of Europe in integrated global markets, all of these issues are of interest to non-Europeans. Finally, the European experience of cooperation might well provide lessons for others as to how to improve global financial cooperation.

\subsubsection{Internal implications}

\subsubsection{Incentive structures for sound banking}

Sound banking practices tend to be discouraged by the likelihood of state bailouts, particularly if the shareholders and management are left intact. Competition policy at the EU level strongly discourages such interference yet, given the current degree of state involvement in the national banking systems of many countries, it may be politically hard to avoid for some years to come (see Table 19). The continuing important role of mutual and cooperative banks in some European countries is a further complication. However, with time, a different set of problems could emerge. A successful process of consolidation could result in a smaller number of international financial institutions (with no truly national affiliation other than legal incorporation) which might 
begin to consider themselves either too big or too complex to fail. In such a multinational context, and one without a central fiscal authority, the difficulties of organising a bailout even for an individual bank could be considerable. Perhaps the good news is that knowledge of this fact would be a welcome incentive for more prudent private sector behaviour.

Deposit insurance has obvious merits but there can be associated incentive problems as well. In Europe, the Directive on Deposit Guarantee Schemes (adopted on 30th May 1994) ensures that all EU countries offer a minimum level of deposit insurance, though there continue to be significant differences in these schemes across countries. ${ }^{45}$ While deposit insurance may make depositors less careful in their choice of bank, this may not be of major concern given that the insurance limit is explicit (barring expectations of a bailout), that it is has often been set at a relatively low level, and that higher insurance levels may be matched (as in Germany) by commensurately strict supervision. However, another problem is that deposit insurance schemes differ across European countries and are essentially "home"-determined. With a single currency, this could lead to an increased flow of deposits to banks domiciled in the most heavily insured jurisdiction, assuming their deposit insurance covers non-residents. ${ }^{46}$ In recognition of this problem, it has recently been agreed that (until 31st December 1999) home-country protection schemes offered by branches abroad cannot provide better depositor protection than the host-country scheme. The European Commission is currently preparing a report on the rationale and consequences of the present situation and will report by the end of the decade.

A final issue having to do with incentives is related to the fact that all European sovereign debt is zero-weighted under the Basle Capital Accord and the Capital Adequacy Directive. Since the introduction of the single currency will heighten the credit risk in sovereign debt, these capital provisions may provide an inappropriate incentive for financial institutions to hold sovereign debt. Moreover, most banking systems in Europe (and also pensions funds) tend to hold only debt of their national sovereign, which means a significant degree of exposure should the credit risk of that particular country be revised upwards (see Table 20). ${ }^{47}$ The implication seems to be that any remaining national restrictions on outward portfolio flows should be abolished, and that international diversification of bank assets with respect to sovereign risk should be actively encouraged. As discussed in Section 2.4.1.1, this would also encourage further the development of a single European bond market denominated in euros.

45 See Barth et al. (1996). The minimum amount insured is ECU 20,000. Up to this limit, only $90 \%$ of losses will be reimbursed.

46 As is commonly the case. See Barth et al. (1996), Table 9.

47 Consider the case of Italian or Belgian banks in a situation where very high interest rates were imposed (for whatever reason) in a single currency area. Given high debt ratios in those countries, debt servicing capacity might be called into question and credit premia could rise. Recall as well the arguments put forward in Section 2.3.3. Any such revision of credit ratings would have a direct effect on the value of bank holdings of those securities (see Bruni (1990), p. 250). 


\subsubsection{Preventing and managing banking problems}

A number of supervisory issues arise in the context of the single currency. The first and most important, at least in principle, is whether supervisory authority should rest with the ECB or the national supervisors. At the moment, it is clearly intended that the national supervisory authorities should continue to carry out their current responsibilities. This will have the effect of helping to separate the monetary policy function from the supervisory function, ${ }^{48}$ and of ensuring that supervisors are physically close to those being regulated. Moreover, it would seem broadly consistent with a system of national deposit insurance. However, such a diffuse system will also make it harder to monitor exposure to single creditors borrowing in different parts of the integrated market, and will put a big premium on the efficient exchange of information. It also seems likely to encourage the maintenance of existing differences in both supervisory practices and capital standards among member nations, which, as noted above, continue to impede formation of the single market.

It will be important to maintain an efficient information flow under the currently envisaged supervisory arrangements. About half of the national supervisory authorities are central banks, whereas other agencies are involved in other countries (some attached to treasuries and some not). Domestic relations between these generic groups of institutions have not always been easy, though to date it appears that the different kinds of national supervisors interact in an admirable way at the international level (see Kapstein (1994)). A second problem may be differences of philosophy about the extent to which privileged supervisory information should be shared, not only between institutions, but also between supervisors and those responsible for monetary policy. ${ }^{49} \mathrm{~A}$ third issue has to do with the prospective role of the Banking Supervisory Sub-Committee which meets at the European Monetary Institute. On the one hand, playing up its role implies that non-central-bank officials have an important role within the framework of the ECB. On the other hand, to the extent that its influence is downplayed, that influence might migrate to the Banking Advisory Committee of the European Commission. Since this Committee also includes Treasury representatives, the number of parties requiring to be fully informed about banking sector difficulties rises even further, as does the scope for misunderstanding in times of difficulty.

48 The Bundesbank has traditionally argued that a supervisory role for the central bank may cause it wrongly to subordinate its price stability objective (in setting monetary policy) to the financial stability objective associated with its supervisory function. Concerns have also been expressed that the supervisory function is more easily politicised and that this interference could easily slide over into the monetary area. It should be noted for completeness, however, that the Bundesbank does collect supervisory information for the Federal Banking Supervisory Office.

49 Some would argue that supervisors should not even tell the operational arm of a central bank that an institution was about to fail. Should the central bank close out its position with that institution, it would be accused of "bringing it down". If it did nothing with the information, it would be accused of "wasting the taxpayers' money". On the one hand, this logic ignores the fact that insider information might also help the central bank to better prepare itself to deal with any of the fallout (contagion, etc.) arising from the failure itself. On the other hand, some fear that systemic concerns raised by the disclosure of such information might also lead to an overly expansionary monetary policy. 
A number of commentators (e.g. Levitt (1995)) have suggested that these problems could prove insurmountable and that authority in the supervisory area would tend to migrate to the ECB. ${ }^{50}$ While at present the ECB has only advisory powers in this area, ${ }^{51}$ Article 105.6 of the Maastricht Treaty states that it could be given "specific tasks concerning policies" conditional on a unanimous decision of the Council on a proposal by the Commission. Whether this is a likely development remains to be seen but, barring a major crisis that might call into question existing arrangements, it could well take a very long time. Another development supporting such an outcome would be the creation of big European banks whose "home" supervisor was not obvious. It is also worth noting that, were there to be such a major change in approach, the issue of a pan-European supervisor outside the ECB might also be raised again. Whatever the affiliation of the European supervisor, the character of its mandate (in particular, which institutions to oversee), the legal basis of its powers (powers which are currently based in national legislation) and the methods through which it would be made accountable would all still have to be decided upon.

Some similar issues arise in the context of potential official lending facilities under EMU. Rightly respecting the principle of "constructive ambiguity", the Treaty is unclear whether such a facility should exist, and thus provides no guidance as to whether those potentially involved should be national central banks, the ECB or both. Nor does it assign responsibility for banks whose business is predominantly international. With supervision being conducted by the national authorities, presumably they (if anyone) would be in the best position to advise the national central bank whether an individual bank was solvent and whether liquidity support for the bank was warranted. Moreover, should a bank initially deemed solvent ultimately prove insolvent, it would seem more appropriate that the associated fiscal charge should be borne at the national rather than the European level. ${ }^{52}$ Such an approach might also be thought attractive in that it would contribute to a separation between the official lending function and the monetary policy function. Yet it also seems clear that, in some circumstances, the ECB might also wish to play a lending role. Within the single market created by EMU, there would be a greater chance of contagion across institutions and borders and this could imply the need for a system-wide response. Indeed, responding to a market-wide shortage of liquidity might be thought the natural function of the ECB. However, while the ECB would presumably be monitoring markets in the course of its everyday operations, ${ }^{53}$ it might still be uncomfortably dependent on national supervisors for information that might be crucial in a crisis.

50 Schoenmaker (1995) presents the pros and cons of an intermediate outcome in which a pan-European supervisor might supervise only those large institutions whose failure was thought likely to have systemic implications. National supervisors would concern themselves with all the rest.

51 This contrasts with the US system, where the Federal Reserve Board of Governors has authority over the regional Federal Reserve Banks and exercises it.

52 If this were not so, there would be a clear incentive for national supervisors to deem insolvent banks "solvent" such that the fiscal charge would be borne by others.

53 This would also depend on the extent to which the ECB relied on the national banks to implement monetary policy. If that reliance were as great as the reliance put by the Federal Reserve Board on the Federal Reserve Bank of New York, the ECB might have little hands-on contact. 


\subsubsection{Interest rate effects and financial stability}

During the ERM crisis of 1992, it became clear that the relatively greater reliance on variable rate mortgages in the United Kingdom meant that the effects of monetary tightening on spending propensities was both faster and greater than in France. Given these different circumstances, the French authorities felt able to effect a more successful defence of their currency within the ERM than did the UK authorities. More recently, the BIS (see BIS (1995)) has documented more fully the extent to which the transmission mechanisms of monetary policy seem to differ across the major countries, and the extent to which these differences have their roots in differences in financial structure. ${ }^{54}$ The reaction of loan rates charged by banks (at the margin) is much slower in some European countries than in others. Moreover, in some countries, fixed rate loans and longer-term loans are much more common than in others. Some countries also rely less on credit rationing devices (relatively high downpayments for houses, cars, etc.), implying that much larger swings in interest rates are required to have the same effects on spending. 55

Differences of this sort within a single currency area imply that common short-term interest rate changes will have different effects in different national jurisdictions. ${ }^{56}$ This is obviously of interest for those who will be concerned about the transmission mechanism of monetary policy within EMU. However, these differences in financial structure could potentially have implications for financial stability as well. Suppose interest rates did have to rise significantly to ensure price stability in the European Union as a whole. Those countries in which the impact of this was particularly great, because of their national financial structure, would presumably suffer a commensurate reduction in the quality of both public and private credits. ${ }^{57}$ Moreover, if the national banking system was heavily invested in national government debt (see Section 3.4.1.1 above) and/or was initially weak for other reasons, the direct impact on bank profits could be quite significant. By the same token, any country with a particular tradition of longer-term lending at fixed rates, financed to whatever degree with shorter-term deposits, could find its profits under pressure from this source.

The upshot of this line of thought is that concerns about financial fragility in particular countries could act as a potential constraint on the conduct of monetary policy for the European Union

54 Another useful reference is provided by Barran et al. (1996).

55 An interesting but often unremarked variation on this theme is the way in which German savings banks and cooperatives try to shelter their business clients from interest rate swings. Such behaviour is consistent with the model assumed by Berlin and Mester (1996), but conflicts with most of the recent literature on "credit rationing" which assumes that a separate credit channel makes interest rate swings even more effective. In reality, both hypotheses may be true depending on which set of banks (perhaps differing across countries or by size) one is talking about.

56 In general it would be simpler and therefore preferable to have a common set of transmission processes. Moreover, it would be particularly unfortunate if a country having a relatively fast-acting and powerful response to higher interest rates were to begin from a starting-point of relatively subdued activity due to some asymmetric shock. Conversely, it would be rather fortunate if the starting-point were a relatively higher level of economic activity.

57 The effect on sovereign credit rankings would be particularly severe in cases where the initial level of debt was high and/or its term was relatively short. 
as a whole. It is, of course, likely that the single currency will lead to these structural differences disappearing over time. Indeed, it is evident that, once there is a single money market and bond market, all market interest rates (reflecting shifts in implicit forward yields) should move uniformly in different national jurisdictions, barring shifts in risk premia. Yet other national differences may be longer-lasting, implying that transitional difficulties cannot be wholly ignored. This point is further reinforced if the need for fiscal restraint under the Maastricht Treaty, and potentially further agreements still to be reached, call into question the fiscal capacity of national governments to deal with systemic problems in their national banking system. ${ }^{58}$ The fundamental point is that both a sound financial system and a sound fiscal position will be required to ensure macroeconomic stability after the introduction of the single currency. It is obvious that not having the former threatens the latter, ${ }^{59}$ but the converse may be true as well.

\subsubsection{International implications}

To prognosticate about the possible implications for public policy within Europe, resulting from the possible effects on financial structure of the possible introduction of the euro, involves at least three levels of speculation. To introduce a fourth level, the possible international implications of all the above, is even more fanciful. Yet some broad lines of thought do seem to be suggested, having to do with the harmonisation of domestic financial and regulatory structures, the process of international regulation and supervision, and the specific issue of "host-versus-home" supervision.

A process of enhanced competition within Europe will leave a smaller number of large banks, many of which will have a presence outside Europe. With a view to possible bankruptcy or other difficulties, it would seem all the more desirable to harmonise bankruptcy laws for financial institutions as well as other aspects of the legal and regulatory framework within which such institutions operate. Indeed, it is possible that under the pressure of intensified international competition and concern about regulatory arbitrage a dynamic might arise in the direction of such harmonisation. For example, Barth et al. (1996, pp. 31-32) make a strong case that, compared with emerging standards in Europe, the regulatory burden for financial institutions in the United States is both too heavy and too diffuse. Such pressures for harmonisation are also likely to increase as it becomes clearer that the industrial world's three major financial groupings (North America, Europe, Japan) are all moving towards free trade in financial services, at least within their own geographical area, and that all are now on the road to some version of universal banking as well.

58 A rough measure of how the market might react to this change in perception is the difference in the credit ratings given to banks (by Moody's) on an "ordinary" as opposed to an "intrinsic strength" basis. See Table 19.

59 Caprio and Klingebiel (1996) provide estimates of the direct costs to governments (relative to GDP) of resolving banking crises in Spain (1977 to 1985, 17\%), Finland (1991 to 1993, 8\%), Sweden (1991, 6\%) and Norway (1987 to 1989, 4\%). Honohan (1997) estimates that emerging countries have spent $\$ 250$ billion for the same purpose since 1980. 
The process of international cooperation in the area of regulation and supervision may also change in light of European developments. Regardless of the degree of harmonisation of domestic rules, supervisors will have to cooperate more closely to ensure proper oversight of larger banks with an international presence. Since supervision of financial conglomerates in Europe is already carried out, as much as possible, on a consolidated basis, there may also be increased pressure for a similar approach in other jurisdictions (especially the United States) where this is not currently the case. On the one hand, this would facilitate the pursuit of the "lead regulator" strategy to deal with the problem of international conglomerates. On the other hand, it might increase pressure for a migration of supervisory authority to bodies outside central banks, which some central banks might welcome but others would certainly not. The evolution of supervisory practices in Europe (who, where, what) may also raise further questions. For example, will European banking supervisors increasingly come to the Basle Committee on Banking Supervision with a single voice and, if so, how will that affect the dynamics of achieving consensus: will it be easier or more difficult? If responsibility for supervisory practice migrates to the ECB, what might be the implications for membership of the Basle Committee? In particular, will the current need for international agreements to be ratified by national legislation demand the presence of national supervisors, or not?

A related issue has to do with the question of "home-versus-host" responsibility for supervision. Within Europe, supervisory responsibility is now clearly allocated to home supervisors, and host supervisors (especially in London) are increasingly inclined to remind home supervisors of their responsibilities. It is also the case under the NAFTA that, as Glass-Steagall disappears, foreign branches will replace subsidiaries and home-country supervision may play a greater role in that region too (see White (1994), p. 18). This raises the possibility of a worldwide agreement to accept home-country supervision, presumably also based on consolidated reporting. Such an agreement would have some obvious advantages. For example, it might eventually allow both internationally active firms and their supervisors to take due account of the global risks being assumed by individual firms as well as the interrelationships between separate categories of risk. This would certainly be the hope of financial institutions themselves. In contrast, the practical difficulties involved in potentially entrusting small countries (with commensurate supervisory capacities) with much larger responsibilities than hitherto should not be underestimated. 
Tables

Table 1

Profitability of major banks in 1994 and 1995

\begin{tabular}{|c|c|c|c|c|c|c|c|c|c|}
\hline \multirow[t]{3}{*}{ Countries } & \multirow[t]{3}{*}{$\begin{array}{l}\text { Number } \\
\text { of banks }\end{array}$} & \multicolumn{2}{|c|}{$\begin{array}{l}\text { Return on } \\
\text { assets }^{1}\end{array}$} & \multicolumn{2}{|c|}{$\begin{array}{l}\text { Loan loss } \\
\text { provisions }\end{array}$} & \multicolumn{2}{|c|}{$\begin{array}{c}\text { Net interest } \\
\text { margin }\end{array}$} & \multicolumn{2}{|c|}{ Operating costs } \\
\hline & & 1994 & 1995 & 1994 & 1995 & 1994 & 1995 & 1994 & 1995 \\
\hline & & \multicolumn{8}{|c|}{ as a percentage of total assets } \\
\hline Denmark $^{2}$ & 2 & 0.29 & 1.20 & 0.61 & 0.42 & 2.85 & 2.55 & 2.20 & 2.07 \\
\hline Finland ${ }^{3}$ & 2 & -0.69 & -0.16 & 1.65 & 0.60 & 1.98 & 1.57 & 2.30 & 2.21 \\
\hline France & 6 & 0.17 & 0.27 & 0.63 & 0.39 & 1.60 & 1.54 & 2.04 & 2.00 \\
\hline Germany & 2 & 0.52 & 0.56 & 0.35 & 0.23 & 1.82 & 1.57 & 2.06 & 1.98 \\
\hline Netherlands & 3 & 0.69 & 0.72 & n.a. & n.a. & 2.27 & 2.18 & 2.17 & 2.26 \\
\hline Norway & 4 & 1.31 & 1.81 & 0.16 & -0.38 & 2.96 & 2.86 & 2.82 & 3.01 \\
\hline Spain & 6 & 0.70 & 0.79 & 0.52 & 0.45 & 2.47 & 2.46 & 2.45 & 2.62 \\
\hline Sweden & 4 & 0.55 & 1.23 & 1.09 & 0.59 & 2.34 & 2.39 & 1.76 & 1.81 \\
\hline United Kingdom & 4 & 1.22 & 1.27 & 0.31 & 0.34 & 2.45 & 2.44 & 3.02 & 2.98 \\
\hline Memorandum: & & & & & & & & & \\
\hline Japan $^{4}$ & 21 & -0.21 & -0.75 & 0.88 & 2.03 & 0.90 & 1.01 & 0.74 & 0.74 \\
\hline Switzerland & 3 & 0.63 & 0.52 & 0.30 & 0.33 & 1.17 & 1.07 & 2.17 & 2.18 \\
\hline United States & 12 & 1.81 & 1.87 & 0.33 & 0.31 & 3.57 & 3.35 & 3.80 & 3.49 \\
\hline
\end{tabular}

Table 2

Long-term accounting indicators of banks' performance ${ }^{1}$

\begin{tabular}{|c|c|c|c|c|c|c|}
\hline \multirow{3}{*}{ Countries } & \multicolumn{3}{|c|}{ Pre-tax profits } & \multicolumn{3}{|c|}{ Non-interest income } \\
\hline & $1980-82^{2}$ & $1986-88$ & $1990-94$ & $1980-82^{2}$ & $1986-88$ & $1990-94$ \\
\hline & \multicolumn{3}{|c|}{ as a percentage of assets } & \multicolumn{3}{|c|}{ as a percentage of gross income } \\
\hline Belgium & 0.4 & 0.4 & 0.3 & 15 & 22 & 26 \\
\hline Finland & 0.5 & 0.5 & -1.6 & 49 & 58 & 53 \\
\hline France & 0.4 & 0.4 & -0.1 & 16 & 17 & 46 \\
\hline Germany & 0.5 & 0.7 & 0.5 & 29 & 30 & 29 \\
\hline Italy & 0.7 & 1.0 & 0.8 & 26 & 29 & 26 \\
\hline Netherlands & 0.3 & 0.7 & 0.6 & 25 & 26 & 30 \\
\hline Norway & 0.6 & 0.0 & 0.2 & 27 & 30 & 29 \\
\hline Spain & 0.7 & 1.1 & 0.6 & 18 & 20 & 27 \\
\hline Sweden & 0.3 & 0.8 & 0.5 & 30 & 31 & 44 \\
\hline United Kingdom & 1.1 & 1.0 & 0.7 & 29 & 37 & 43 \\
\hline \multicolumn{7}{|l|}{ Memorandum: } \\
\hline Japan $^{3}$ & 0.5 & 0.6 & 0.2 & 14 & 24 & 1 \\
\hline Switzerland & 0.6 & 0.7 & 0.6 & 47 & 49 & 51 \\
\hline United States & 1.0 & 0.7 & 1.6 & 24 & 30 & 35 \\
\hline \multicolumn{7}{|c|}{$\begin{array}{l}{ }^{1} \text { For Belgium, the Netherlands and Switzerland, all banks; for other countries, commercial banks only. }{ }^{2} \text { For Belgium and France, } \\
1981-82 .{ }^{3} \text { Fiscal years. }\end{array}$} \\
\hline
\end{tabular}


Table 3

Long-term movements in bank share prices

\begin{tabular}{|c|c|c|c|c|c|c|c|}
\hline \multirow[t]{2}{*}{ Countries } & 1970 & $1980-82$ & $1984-86$ & $1990-92$ & $1993-95$ & 1995 & 1996 \\
\hline & \multicolumn{7}{|c|}{ ratio of bank ${ }^{1}$ index to overall index, $1980=100$} \\
\hline Belgium & 110 & 97 & 93 & 109 & 155 & 166 & 182 \\
\hline Finland & 85 & 98 & 84 & 47 & 22 & 15 & 13 \\
\hline Germany & 93 & 94 & 83 & 75 & 78 & 72 & 67 \\
\hline Italy & n.a. & 138 & 96 & 86 & 72 & 67 & 65 \\
\hline Netherlands & n.a. & 92 & 77 & 56 & 61 & 60 & 64 \\
\hline Norway & 101 & 103 & 67 & 17 & 9 & 9 & 10 \\
\hline Spain & 56 & 112 & 78 & 85 & 76 & 72 & 70 \\
\hline Sweden & 66 & 99 & 84 & 68 & 66 & 61 & 66 \\
\hline United Kingdom & 85 & 97 & 90 & 83 & 118 & 127 & 143 \\
\hline \multicolumn{8}{|l|}{ Memorandum: } \\
\hline Japan & 71 & 103 & $158^{2}$ & 189 & 196 & 194 & 181 \\
\hline Switzerland & 64 & 99 & 92 & 59 & 60 & 55 & 49 \\
\hline United States & 142 & 111 & 120 & 69 & 92 & 96 & 111 \\
\hline
\end{tabular}

Table 4

\section{Bank share in financial intermediation in $\mathbf{1 9 9 5}$}

\begin{tabular}{|c|c|c|c|c|}
\hline \multirow[t]{3}{*}{ Countries } & \multicolumn{4}{|c|}{ Assets of banks as a percentage of assets of banks and non-bank financial institutions } \\
\hline & \multirow[t]{2}{*}{ Total } & \multicolumn{2}{|c|}{ of which } & \multirow{2}{*}{$\begin{array}{c}\text { Memo: } \\
\text { Share of state- } \\
\text { owned banks }{ }^{1}\end{array}$} \\
\hline & & Savings banks & $\begin{array}{c}\text { Mutual and } \\
\text { cooperative banks }\end{array}$ & \\
\hline Finland $^{2}$ & 59 & n.a. & n.a. & n.a. \\
\hline France & 73 & 8 & 15 & 12 \\
\hline Germany & 77 & 36 & 14 & 50 \\
\hline Italy & 81 & n.a. & 16 & 60 \\
\hline Netherlands $^{2}$ & 52 & n.a. & n.a. & n.a. \\
\hline Norway & 63 & 19 & n.a. & 13 \\
\hline Spain & 78 & 26 & 3 & n.a. \\
\hline United Kingdom & $56^{3}$ & n.a. & n.a. & 0 \\
\hline Memorandum: & & & & \\
\hline$J_{a p a n^{2}}$ & 79 & n.a. & n.a. & 0 \\
\hline Switzerland ${ }^{2}$ & 53 & 3 & 5 & $3^{4}$ \\
\hline United States & 22 & 4 & 1 & 0 \\
\hline
\end{tabular}


Table 6

Transactions in interest rate swaps and swaptions in dollars, yen and euros

\begin{tabular}{|c|c|c|c|}
\hline \multirow[b]{4}{*}{ 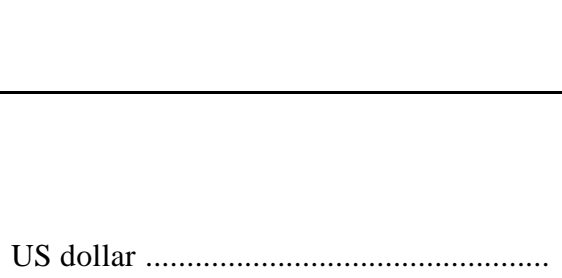 } & Central bank & \multicolumn{2}{|c|}{ ISDA } \\
\hline & \multicolumn{2}{|c|}{1995} & $1996^{2}$ \\
\hline & \multicolumn{3}{|c|}{ in trillions of dollars per annum } \\
\hline & 5.981 & \multirow{3}{*}{2.856} & \multirow{3}{*}{3.690} \\
\hline 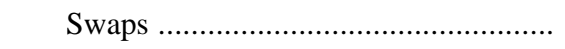 & 4.283 & & \\
\hline Swaptions ............................................ & 1.698 & & \\
\hline 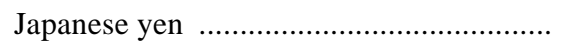 & 4.904 & \multirow{3}{*}{2.259} & \multirow{3}{*}{3.128} \\
\hline 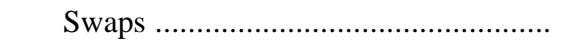 & 4.378 & & \\
\hline 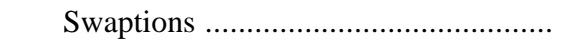 & 0.527 & & \\
\hline Selected European currencies ..................... & 4.678 & \multirow{3}{*}{2.315} & \multirow{3}{*}{3.485} \\
\hline 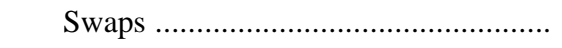 & 3.907 & & \\
\hline 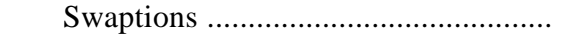 & 0.771 & & \\
\hline 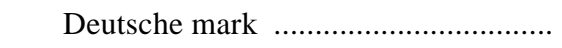 & 1.948 & \multirow{3}{*}{0.985} & \multirow{3}{*}{1.935} \\
\hline 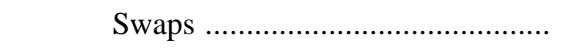 & 1.661 & & \\
\hline Swaptions ...................................... & 0.287 & & \\
\hline 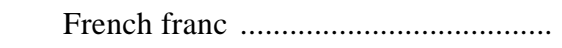 & 2.303 & \multirow{3}{*}{1.113} & \multirow{3}{*}{1.550} \\
\hline 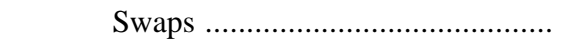 & $1.879^{3}$ & & \\
\hline 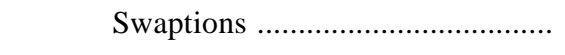 & $0.424^{4}$ & & \\
\hline 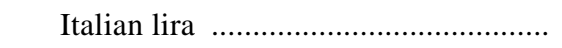 & 0.427 & \multirow{3}{*}{0.217} & \multirow{3}{*}{ n.a. } \\
\hline 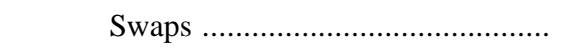 & $0.367^{3}$ & & \\
\hline 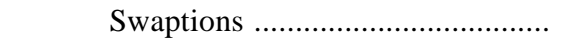 & $0.060^{4}$ & & \\
\hline \multicolumn{4}{|c|}{$\begin{array}{l}{ }^{1} \text { Estimated as average daily turnover in April times } 255 .{ }^{2} \text { First half, at annual rate. }{ }^{3} \text { Estimated as DM swaps times the ratio of ISDA- } \\
\text { reported French franc swaps or ISDA-reported Italian lira swaps to ISDA-reported DM swaps. }{ }^{4} \text { Estimated as DM swaptions times the } \\
\text { ratio of swaption transactions in Paris or Milan to such transactions in Frankfurt. }\end{array}$} \\
\hline
\end{tabular}


Table 7

Currency and home-country relationship in the choice of bond bookrunner, 1996

Percentage market share won by bookrunners of indicated nationality

\begin{tabular}{|c|c|c|c|c|c|c|c|}
\hline \multicolumn{4}{|c|}{ German bookrunners } & \multicolumn{4}{|c|}{ French bookrunners } \\
\hline \multirow[t]{2}{*}{ Borrower } & \multicolumn{3}{|c|}{ Currency } & \multirow[t]{2}{*}{ Borrower } & \multicolumn{3}{|c|}{ Currency } \\
\hline & Mark & Other & All & & $\begin{array}{l}\text { French } \\
\text { franc }\end{array}$ & Other & All \\
\hline German & 44 & 16 & 24 & French & 86 & 10 & 25 \\
\hline Other & 37 & 2 & 5 & Other & 75 & 2 & 5 \\
\hline All & 39 & 4 & 8 & All & 77 & 2 & 6 \\
\hline \multicolumn{4}{|c|}{ UK bookrunners } & \multicolumn{4}{|c|}{ Dutch bookrunners } \\
\hline \multirow[t]{2}{*}{ Borrower } & \multicolumn{3}{|c|}{ Currency } & \multirow[t]{2}{*}{ Borrower } & \multicolumn{3}{|c|}{ Currency } \\
\hline & Pound & Other & All & & Guilder & Other & All \\
\hline UK & 40 & 21 & 31 & Dutch & 83 & 26 & 48 \\
\hline Other & 48 & 3 & 5 & Other & 85 & 2 & 3 \\
\hline All & 44 & 4 & 7 & All & 84 & 2 & 5 \\
\hline \multicolumn{4}{|c|}{ US bookrunners } & \multicolumn{4}{|c|}{ Japanese bookrunners } \\
\hline \multirow[t]{2}{*}{ Borrower } & \multicolumn{3}{|c|}{ Currency } & Borrower & \multicolumn{3}{|c|}{ Currency } \\
\hline & Dollar & Other & All & & Yen & Other & All \\
\hline US & 86 & 46 & 76 & Japanese & 75 & 46 & 59 \\
\hline Other & 54 & 13 & 28 & Other & 87 & 6 & 14 \\
\hline All & 64 & 16 & 37 & All & 84 & 8 & 17 \\
\hline \multicolumn{8}{|c|}{$\begin{array}{l}\text { Note: Each entry shows market share of German, French, UK, Dutch, US or Japanese bookrunners for issuers of the indicated nationality } \\
\text { in the indicated currency. For example, the } 44 \% \text { in the upper left-hand corner means that German underwriters ran the books for } 44 \% \text { of } \\
\text { the bonds of German issuers that were denominated in marks. Data include all bonds in the Euromoney database, including international } \\
\text { bonds issued under medium-term note programmes, that are not equity-related. Total amount of bond issuance by currency: DM: } \$ 81 \\
\text { billion; French franc: } \$ 37 \text { billion; pound: } \$ 54 \text { billion; guilder: } \$ 22 \text { billion; dollar: } \$ 319 \text { billion; yen: } \$ 91 \text { billion; grand total: } \$ 725 \text { billion. } \\
\text { Sources: Euromoney Bondware and BIS. }\end{array}$} \\
\hline
\end{tabular}


Table 8

EMU membership poll results and sovereign credit ratings

\begin{tabular}{|c|c|c|c|c|c|}
\hline \multirow[t]{2}{*}{ Countries } & \multicolumn{2}{|c|}{$\begin{array}{l}\text { Expected participation in EMU at outset (in \%) } \\
\text { poll published in }\end{array}$} & \multicolumn{3}{|c|}{ Rating $^{2}$} \\
\hline & January 1996 & August 1996 & Moody's & S\&P's & IBCA \\
\hline Germany & 100 & 100 & Aaa & AAA & AAA \\
\hline France & 97 & 100 & Aaa & AAA & AAA \\
\hline Netherlands & 76 & 100 & Aaа & AAA & AAA \\
\hline Belgium & 79 & 95 & Aa1 & AA+ & AA+ \\
\hline Austria & 79 & 93 & Aaa & AAA & AAA \\
\hline Ireland & 60 & 82 & Aa1 & AA & $\mathrm{AA}+$ \\
\hline Finland & 36 & 48 & Aa1 & AA & AAA \\
\hline Denmark & 50 & 43 & Aa1 & $\mathrm{AA}+$ & $\mathrm{AA}+$ \\
\hline Sweden & 7 & 13 & Aa3 & AA+ & AA- \\
\hline United Kingdom & 22 & 8 & Aaa & AAA & AAA \\
\hline Spain & 7 & 7 & $\mathrm{Aa} 2$ & AA & AA \\
\hline Portugal & 0 & 4 & Aa3 & AA- & AA- \\
\hline Italy & 2 & 3 & Aa3 & AA & AA- \\
\hline Greece & 0 & 0 & Baa1 & BBB- & BBB- \\
\hline \multicolumn{6}{|c|}{$\begin{array}{l}{ }^{1} \text { The polls of over } 200 \text { financial and economic forecasters indicate the percentage of respondents predicting that countries will join EMU } \\
\text { at the outset. Respondents' assumptions regarding the likely starting date differed. Luxembourg, rated Aaa and AAA respectively, was } \\
\text { not included in the poll. }{ }^{2} \text { Ratings refer to foreign currency issues. }\end{array}$} \\
\hline
\end{tabular}

Table 9

Derivative transactions in long-term government securities in dollars, yen and euros

\begin{tabular}{|c|c|c|c|c|c|c|c|}
\hline \multirow[t]{4}{*}{ Bonds and notes } & \multicolumn{3}{|c|}{1995} & \multicolumn{2}{|c|}{1996} & \multirow{2}{*}{\multicolumn{2}{|c|}{$\begin{array}{c}\text { Memo: } \\
\text { Cash market }\end{array}$}} \\
\hline & \multirow[t]{2}{*}{ Futures } & \multicolumn{2}{|c|}{ Options } & \multirow[t]{2}{*}{ Futures } & \multirow{2}{*}{$\begin{array}{c}\text { Options } \\
\text { Exchange- } \\
\text { traded }\end{array}$} & & \\
\hline & & $\begin{array}{l}\text { Exchange- } \\
\text { traded }\end{array}$ & OTC $^{1}$ & & & Trading & Outstandings \\
\hline & \multicolumn{7}{|c|}{ in trillions of dollars per annum } \\
\hline US Treasuries & 12.374 & 3.627 & 0.435 & 12.011 & 3.667 & 35.843 & 2.547 \\
\hline $\begin{array}{l}\text { Japanese government } \\
\text { bonds }\end{array}$ & 15.956 & 2.163 & 1.539 & 12.262 & 1.824 & 6.502 & 1.996 \\
\hline $\begin{array}{l}\text { Selected European } \\
\text { government bonds }\end{array}$ & 14.067 & 2.384 & 0.465 & 17.848 & 2.759 & 18.225 & 1.608 \\
\hline German bonds & 9.090 & 1.274 & 0.173 & 12.388 & 1.550 & 16.566 & 0.727 \\
\hline French bonds & 3.367 & 0.954 & $0.256^{2}$ & 3.452 & 0.869 & 1.658 & 0.490 \\
\hline Italian bonds & 1.610 & 0.156 & 0.036 & 2.008 & 0.340 & $0.420^{3}$ & $0.391^{4}$ \\
\hline \multicolumn{8}{|c|}{$\begin{array}{l}\text { Note: Data on cash market trading and outstandings are for } 1995 \text { and end-1995 respectively. } \\
{ }^{1} \text { Estimated as average daily turnover in April times } 255 .{ }^{2} \text { Estimated as OTC trading in interest rate options on traded securities in } \\
\text { Deutsche marks times the ratio of total OTC trading in interest rate options in Paris or Milan to that in Frankfurt. }{ }^{3} \text { Euroclear and Cedel } \\
\text { only. }{ }^{4} \text { Lira-denominated Treasury bonds only; excludes variable rate notes. } \\
\text { Sources: Salomon Brothers, Central Bank Survey of Foreign Exchange and Derivatives Market Activity 1995, various futures exchanges } \\
\text { and national sources. }\end{array}$} \\
\hline
\end{tabular}


Table 10

Effect of EMU on central government debt ratings

\begin{tabular}{|c|c|c|c|c|c|c|c|c|c|}
\hline \multirow[t]{2}{*}{ Countries } & \multicolumn{3}{|c|}{ Moody's } & \multicolumn{3}{|c|}{ Standard \& Poor's } & \multicolumn{3}{|c|}{ IBCA } \\
\hline & FX & Dom & EMU & FX & Dom & EMU & FX & Dom & EMU \\
\hline Austria & Aaa & $\mathrm{nr}$ & Aaa & AAA & AAA & AAA & AAA & AAA & AAA \\
\hline France & Aaa & Aaa & Aaa & AAA & AAA & AAA & AAA & AAA & AAA \\
\hline Germany & Aaа & Aaa & Aaa & AAA & AAA & AAA & AAA & AAA & AAA \\
\hline Luxembourg & Aaa & $\mathrm{nr}$ & Aaа & AAA & AAA & AAA & AAA & AAA & AAA \\
\hline Netherlands & Aaa & Aaа & Aaa & AAA & AAA & AAA & AAA & AAA & AAA \\
\hline United & Aaа & Aaа & Aaa & AAA & AAA & AAA & AAA & AAA & $\mathrm{amb}$ \\
\hline \multicolumn{10}{|l|}{ Kingdom } \\
\hline Belgium & Aal & Aa1 & Aa1 & $\mathrm{AA}+$ & AAA & $\mathrm{AA}+$ & $\mathrm{AA}+$ & AAA & pos \\
\hline Denmark & Aal & Aa1 & Aa1 & AA+ & AAA & $\mathrm{AA}+$ & AA+ & AAA & pos \\
\hline Finland & Aa1 & Aaa & Aaa & $\mathrm{AA}$ & AAA & $\mathrm{AA}$ & AAA & AAA & $\mathrm{amb}$ \\
\hline Greece & Baa1 & A2 & A2 & BBB- & $\mathrm{nr}$ & BBB- & BBB- & $\mathrm{nr}$ & $\mathrm{amb}$ \\
\hline Ireland & Aa1 & Aaa & Aaa & AA & AAA & AA & $\mathrm{AA}+$ & AAA & $\mathrm{amb}$ \\
\hline Italy & Aa3 & Aa3 & Aa3 & AA & AAA & $\mathrm{AA}$ & AA- & AAA & pos \\
\hline Portugal & Aa3 & $\mathrm{Aa} 2$ & $\mathrm{Aa} 2$ & AA- & AAA & AA- & AA- & AAA & $a m b$ \\
\hline Spain & $\mathrm{Aa} 2$ & $\mathrm{Aa} 2$ & $\mathrm{Aa} 2$ & $\mathrm{AA}$ & AAA & $\mathrm{AA}$ & $\mathrm{AA}$ & AAA & pos \\
\hline Sweden & $\mathrm{Aa3}$ & $\mathrm{nr}$ & $\mathrm{nr}$ & $\mathrm{AA}+$ & AAA & $\mathrm{AA}+$ & AA- & AAA & $\mathrm{amb}$ \\
\hline \multicolumn{10}{|c|}{$\begin{array}{l}\text { Note: For each rating agency, FX indicates the current foreign currency rating, Dom the current domestic debt rating and EMU the } \\
\text { prospective unified rating under the hypothesis of participation in the single money. } n r \text { denotes no rating; for IBCA, amb denotes } \\
\text { ambiguous effect and pos denotes positive effect. }\end{array}$} \\
\hline
\end{tabular}

Table 11

International security issues by issue size and currency

\begin{tabular}{|c|c|c|c|}
\hline \multirow[t]{3}{*}{ Currencies, by region } & \multicolumn{2}{|c|}{ Size of issue } & \multirow[t]{2}{*}{ Tota } \\
\hline & $<\$ 1.0$ bn & $\geq \$ 1.0$ bn & \\
\hline & \multicolumn{3}{|c|}{ in billions of US dollars, 1990-95 } \\
\hline Developing countries & 141.7 & 10.5 & 152.2 \\
\hline US dollar & 96.8 & 7.4 & 104.2 \\
\hline EU currencies & 17.6 & 0.0 & 17.6 \\
\hline Japanese yen & 27.3 & 3.2 & 30.5 \\
\hline Developed countries & $1,555.7$ & 209.1 & $1,764.8$ \\
\hline US dollar & 554.9 & 119.5 & 674.4 \\
\hline EU currencies & 660.1 & 58.9 & 719.0 \\
\hline Japanese yen & 340.8 & 30.6 & 371.4 \\
\hline International institutions & 117.1 & 39.9 & 216.9 \\
\hline US dollar & 34.1 & 15.0 & 49.1 \\
\hline EU currencies & 113.9 & 15.3 & 129.3 \\
\hline Japanese yen & 29.1 & 9.5 & 38.6 \\
\hline Total & $1,874.5$ & 259.5 & $2,134.0$ \\
\hline US dollar & 685.8 & 141.9 & 827.7 \\
\hline EU currencies & 791.6 & 74.3 & 865.9 \\
\hline Japanese yen & 397.1 & 43.3 & 440.4 \\
\hline $\begin{array}{l}\text { Grand total, including offshore } \\
\text { centres }\end{array}$ & $2,078.6$ & 276.9 & $2,355.5$ \\
\hline
\end{tabular}


Table 12

\section{Currency composition of developing country debt}

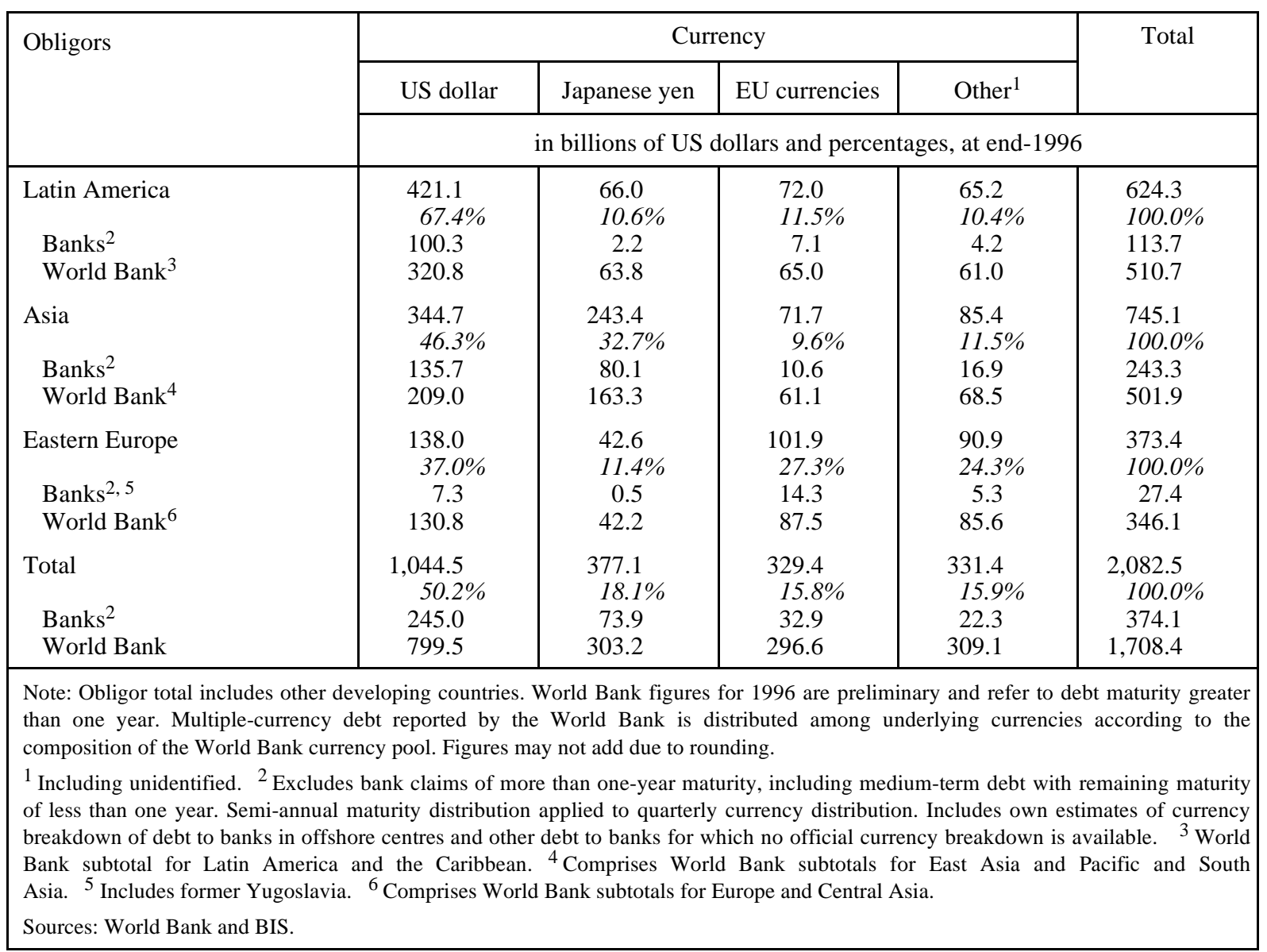

Table 13

Currency and home-country relationship in the choice of syndicated loan arranger, 1996

Percentage market share won by arrangers of indicated nationality

\begin{tabular}{|c|c|c|c|c|c|c|c|}
\hline \multicolumn{4}{|c|}{ German arranger banks } & \multicolumn{4}{|c|}{ French arranger banks } \\
\hline \multirow[t]{2}{*}{ Borrower } & \multicolumn{3}{|c|}{ Currency } & \multirow[t]{2}{*}{ Borrower } & \multicolumn{3}{|c|}{ Currency } \\
\hline & Mark & Other & All & & $\begin{array}{l}\text { French } \\
\text { franc }\end{array}$ & Other & All \\
\hline German & 82 & 71 & 80 & French & 46 & 10 & 39 \\
\hline Other & 46 & 3 & 4 & Other & 56 & 2 & 2 \\
\hline All & 62 & 3 & 4 & All & 47 & 2 & 3 \\
\hline \multicolumn{4}{|c|}{ UK arranger banks } & \multicolumn{4}{|c|}{ US arranger banks } \\
\hline \multirow[t]{2}{*}{ Borrower } & \multicolumn{3}{|c|}{ Currency } & Borrower & \multicolumn{3}{|c|}{ Currency } \\
\hline & Pound & Other & All & & Dollar & Other & All \\
\hline UK & 56 & 39 & 53 & US & 83 & 28 & 82 \\
\hline Other & 24 & 2 & 2 & Other & 27 & 13 & 20 \\
\hline All & 53 & 3 & 6 & All & 71 & 13 & 61 \\
\hline \multicolumn{8}{|c|}{$\begin{array}{l}\text { Note: Each entry shows market share of German, French, UK or US banks as arrangers of loans for borrowers of the indicated nationality } \\
\text { in the indicated currency. For example, the } 82 \% \text { in the upper left-hand corner means that German banks arranged } 82 \% \text { of the loans for } \\
\text { German borrowers that were denominated in marks. Data include all loans in the Euromoney database that were signed and for which } \\
\text { amounts were given, and are therefore more inclusive than the usual data reported by the BIS, which exclude, inter alia, refinancing. } \\
\text { Total syndicated loan amounts by currency: DM: } \$ 25 \text { billion; French franc: } \$ 31 \text { billion; pound: } \$ 102 \text { billion; dollar: } \$ 1,254 \text { billion; grand } \\
\text { total: } \$ 1,514 \text { billion. }\end{array}$} \\
\hline \multicolumn{8}{|c|}{ Sources: Euromoney Bondware and BIS. } \\
\hline
\end{tabular}


Table 16

Banks' restructuring: number of branches ${ }^{1}$

\begin{tabular}{|c|c|c|c|c|c|c|c|}
\hline \multirow[t]{2}{*}{ Countries } & $1980^{2}$ & 1990 & $1995^{3}$ & \multicolumn{3}{|c|}{ Peak (since 1980) } & \multirow{2}{*}{$\begin{array}{c}\text { Memo: } \\
\text { Bank } \\
\text { density }^{5}\end{array}$} \\
\hline & \multicolumn{4}{|c|}{ number (in thousands) } & year & $\%$ & \\
\hline Belgium & 7.8 & 8.3 & 7.8 & 8.5 & 1989 & -8 & 0.77 \\
\hline Finland & 3.4 & 3.3 & 2.1 & 3.5 & 1988 & -39 & 0.42 \\
\hline France & 24.3 & 25.7 & 25.5 & 25.9 & 1987 & -2 & 0.44 \\
\hline Germany $^{6}$ & 39.3 & 39.8 & 37.9 & 40.0 & 1985 & -5 & 0.46 \\
\hline Italy & 12.2 & 17.7 & 23.9 & 23.9 & 1995 & - & 0.42 \\
\hline Netherlands & 5.5 & 8.0 & 7.3 & 8.0 & 1989 & -9 & 0.47 \\
\hline Norway & 1.9 & 1.8 & 1.4 & 2.2 & 1987 & -37 & 0.36 \\
\hline Spain & 25.8 & 35.2 & 36.0 & 36.0 & 1995 & - & 0.92 \\
\hline Sweden & 3.7 & 3.3 & 2.7 & 3.7 & 1980 & -27 & 0.31 \\
\hline United Kingdom & 20.4 & 19.0 & 16.6 & 21.2 & 1985 & -22 & 0.28 \\
\hline Memorandum: & & & & & & & \\
\hline Japan & 18.5 & 24.8 & 25.7 & 25.7 & 1994 & - & 0.21 \\
\hline Switzerland & 3.7 & 4.2 & 3.8 & 4.2 & 1990 & -10 & 0.53 \\
\hline United States & 58.3 & 67.7 & 69.6 & 69.6 & 1994 & - & 0.27 \\
\hline \multicolumn{8}{|c|}{$\begin{array}{l}{ }^{1} \text { Deposit-taking institutions; for Japan and the United States, excluding various types of credit cooperative. }{ }^{2} \text { For France and the } \\
\text { Netherlands, } 1981 .{ }^{3} \text { For Belgium, Finland, the Netherlands, Sweden, the United Kingdom, Japan, Switzerland and the United States, } \\
1994 .{ }^{4} \text { From peak to most recent observation where applicable. }{ }^{5} \text { Number of branches per } 1,000 \text { inhabitants in the latest available } \\
\text { year. }{ }^{6} \text { Western Germany only, excluding commission agencies of Bausparkassen. Data for the whole of Germany: 1995, 48.2; } \\
\text { percentage change, }-2 \% \text {. } \\
\text { Sources: British Bankers' Association, Building Societies' Association and national data. }\end{array}$} \\
\hline
\end{tabular}


Table 17

Banks' restructuring: employment and staff costs

\begin{tabular}{|c|c|c|c|c|c|c|c|c|c|}
\hline \multirow{3}{*}{ Countries } & \multicolumn{6}{|c|}{ Employment $^{1}$} & \multicolumn{3}{|c|}{ Staff costs ${ }^{2}$} \\
\hline & $1980^{3}$ & 1990 & $1994^{4}$ & \multicolumn{3}{|c|}{ Peak (since 1980) } & 1980- & 1986- & 1992- \\
\hline & \multicolumn{4}{|c|}{ number (in thousands) } & year & $\begin{array}{c}\% \\
\text { change }^{6}\end{array}$ & \multicolumn{3}{|c|}{$\begin{array}{l}\text { as a percentage of gross } \\
\text { income }\end{array}$} \\
\hline Belgium & 68 & 79 & 76 & 79 & 1990 & -5 & 41 & 33 & $39^{7}$ \\
\hline Finland & 42 & 50 & 36 & 53 & 1989 & -32 & 43 & 33 & 24 \\
\hline France & 399 & 399 & 382 & 401 & 1988 & -5 & 47 & 44 & 44 \\
\hline Germany $^{8}$ & 533 & 621 & 658 & 658 & 1994 & - & 48 & 44 & 39 \\
\hline Italy & 277 & 324 & 332 & 333 & 1993 & -0.3 & 46 & 48 & 44 \\
\hline Netherlands & 113 & 118 & 112 & 119 & 1991 & -6 & 42 & 41 & 38 \\
\hline Norway & 24 & 31 & 23 & 35 & 1987 & -34 & 42 & 35 & 30 \\
\hline Spain & 252 & 252 & 245 & 256 & 1991 & -4 & 47 & 43 & 37 \\
\hline Sweden & 39 & 45 & 42 & 46 & 1991 & -5 & 29 & 23 & 22 \\
\hline United Kingdom & 324 & 425 & 368 & 430 & 1989 & -15 & 47 & 38 & 36 \\
\hline \multicolumn{10}{|l|}{ Memorandum: } \\
\hline Japan & 612 & 597 & 618 & 622 & 1993 & -0.6 & 44 & 33 & 39 \\
\hline Switzerland & 84 & 120 & 112 & 120 & 1990 & -7 & 40 & 37 & 33 \\
\hline United States $^{9}$ & 1,900 & 1,979 & 1,891 & 2,136 & 1987 & -12 & 36 & 31 & 27 \\
\hline \multicolumn{10}{|c|}{$\begin{array}{l}{ }^{1} \text { In deposit-taking institutions; for Japan, excluding credit cooperatives. }{ }^{2} \text { For Belgium, the Netherlands and Switzerland, all banks; for } \\
\text { other countries, commercial banks (OECD definition). }{ }^{3} \text { For France, 1985; for the Netherlands and Sweden, 1984; for Spain, } \\
\text { 1981. }{ }^{4} \text { For Italy, Norway and Spain, 1995. }{ }^{5} \text { For Belgium and France, 1981-82. }{ }^{6} \text { From peak to most recent observation where } \\
\text { applicable. }{ }^{7} 1992 .{ }^{8} \text { For employment, western Germany only. Data for the whole of Germany: 1994, } 728 .{ }^{9} \text { Employment data } \\
\text { excluding credit unions: } 1994,1,732 \text {; percentage change, }-14 \% \text {. }\end{array}$} \\
\hline
\end{tabular}


Table 18

Merger and acquisition activity in banking ${ }^{1}$

\begin{tabular}{|c|c|c|c|c|c|c|c|c|c|}
\hline \multirow[t]{3}{*}{ Countries } & \multicolumn{3}{|c|}{ Number } & \multicolumn{6}{|c|}{ Value } \\
\hline & & & & \multicolumn{3}{|c|}{ in billions of US dollars } & \multicolumn{3}{|c|}{ as a percentage ${ }^{2}$} \\
\hline & $91-92$ & $93-94$ & $95-96^{3}$ & $91-92$ & $93-94$ & $95-96^{3}$ & $91-92$ & $93-94$ & $95-96^{3}$ \\
\hline Belgium & 22 & 18 & 12 & 1.0 & 0.6 & 0.4 & 14.1 & 7.0 & 7.9 \\
\hline Finland & 51 & 16 & 4 & 0.9 & 1.0 & 0.8 & 22.3 & 21.7 & 11.3 \\
\hline France & 133 & 71 & 43 & 2.4 & 0.5 & 3.2 & 4.3 & 1.0 & 10.4 \\
\hline Germany & 71 & 83 & 27 & 3.5 & 1.9 & 0.7 & 6.5 & 7.6 & 3.5 \\
\hline Italy & 122 & 105 & 65 & 5.3 & 6.1 & 3.0 & 15.6 & 17.7 & 19.7 \\
\hline Netherlands & 20 & 13 & 7 & 0.1 & 0.1 & 0.8 & 0.2 & 0.5 & 9.5 \\
\hline Norway & 23 & 24 & 2 & 0.1 & 0.2 & 0.4 & 1.2 & 5.7 & 4.4 \\
\hline Spain & 76 & 44 & 26 & 4.3 & 4.5 & 2.1 & 13.5 & 21.5 & 34.1 \\
\hline Sweden & 38 & 23 & 8 & 1.1 & 0.4 & 0.1 & 3.8 & 2.0 & 0.4 \\
\hline United Kingdom & 71 & 40 & 28 & 7.5 & 3.3 & 21.7 & 6.5 & 3.4 & 12.4 \\
\hline Total & 627 & 437 & 222 & 26.1 & 18.5 & 33.3 & 7.3 & 6.7 & 11.0 \\
\hline $\begin{array}{l}\text { Total non-bank } \\
\text { financial }\end{array}$ & 1,383 & 1,361 & 834 & 28.0 & 38.8 & 27.2 & 7.8 & 14.0 & 9.0 \\
\hline Memorandum: ${ }^{4}$ & & & & & & & & & \\
\hline Japan & 22 & 8 & 17 & 0.0 & 2.2 & 33.8 & 0.3 & 18.8 & 77.0 \\
\hline & $(22)$ & (14) & (17) & $(0.3)$ & $(1.5)$ & $(0.2)$ & (3.6) & $(12.8)$ & $(0.4)$ \\
\hline Switzerland & 47 & 59 & 14 & 0.4 & 3.9 & 0.7 & 9.5 & 43.4 & 1.6 \\
\hline & $(30)$ & (30) & (28) & $(0.4)$ & $(2.0)$ & (1.3) & (9.7) & $(21.9)$ & (3.1) \\
\hline United States & 1,354 & 1,477 & 1,176 & 56.8 & 55.3 & 82.5 & 18.7 & 9.0 & 13.5 \\
\hline & (984) & $(1,426)$ & $(1,125)$ & (30.4) & (72.8) & (56.9) & (10.0) & (11.9) & (9.3) \\
\hline
\end{tabular}


Table 19

Intrinsic strength and ordinary ratings of EU banks

\begin{tabular}{|c|c|c|c|c|}
\hline Countries & $\begin{array}{c}\text { Number of rated } \\
\text { banks }\end{array}$ & Range of BFSRs & Average BFSR & $\begin{array}{c}\text { Average long-term } \\
\text { deposit rating }\end{array}$ \\
\hline 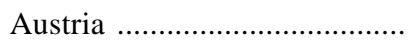 & 7 & $\mathrm{~B}$ to $\mathrm{D}+$ & $\mathrm{C}$ & Aa3 \\
\hline 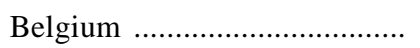 & 7 & $\mathrm{~B}+$ to $\mathrm{C}$ & $\mathrm{B}$ & Aa3 \\
\hline 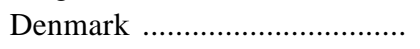 & 3 & $\mathrm{~B}$ to $\mathrm{C}$ & $\mathrm{C}+$ & A1 \\
\hline 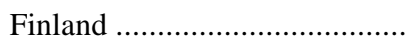 & 4 & $\mathrm{D}+$ to $\mathrm{E}$ & $\mathrm{D}$ & $\mathrm{A} 2$ \\
\hline 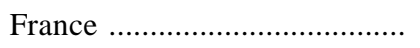 & 27 & $A$ to $\mathrm{D}$ & $\mathrm{C}+$ & A1 \\
\hline 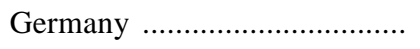 & 21 & $A$ to $\mathrm{D}+$ & $\mathrm{C}+$ & Aa1 \\
\hline Ireland & 4 & $\mathrm{~B}$ to $\mathrm{C}+$ & $\mathrm{B} / \mathrm{C}+$ & A1/A2 \\
\hline Italy & 16 & $\mathrm{~B}$ to $\mathrm{E}$ & $\mathrm{C}$ & A2 \\
\hline 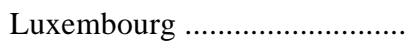 & 3 & $\mathrm{~B}$ & $\mathrm{~B}$ & Aa2 \\
\hline 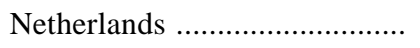 & 5 & $\mathrm{~A}$ to $\mathrm{C}+$ & $\mathrm{B}+$ & Aa1 \\
\hline 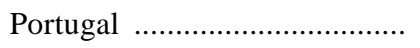 & 3 & $\mathrm{C}+$ to $\mathrm{C}$ & $\mathrm{C}$ & A3 \\
\hline 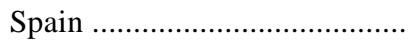 & 11 & $\mathrm{~A}$ to $\mathrm{C}$ & $\mathrm{B}$ & Aa3 \\
\hline Sweden & 4 & $\mathrm{C}+$ to $\mathrm{C}$ & $\mathrm{C}$ & A2 \\
\hline United Kingdom ........................ & 24 & $\mathrm{~A}$ to $\mathrm{C}+$ & $\mathrm{B}$ & A1 \\
\hline
\end{tabular}

Table 20

Claims on central government ${ }^{1}$ as a percentage of total bank assets

\begin{tabular}{|l|c|r|r|r|r|}
\hline Countries & 1975 & 1980 & 1985 & 1990 & 1995 \\
\hline Belgium & 17.5 & 15.3 & 19.2 & 18.6 & 28.9 \\
France & 3.9 & 9.7 & 11.5 & 7.2 & 11.2 \\
Germany & 9.9 & 12.8 & 14.0 & 12.4 & 15.1 \\
Italy & 10.1 & 18.3 & 21.9 & 15.3 & n.a. \\
Spain & n.a. & n.a. & 22.9 & 20.4 & 19.0 \\
United Kingdom ${ }^{2}$ & 5.5 & 3.1 & 1.3 & 0.9 & 1.3 \\
Memorandum: & & & & & \\
United States & 10.0 & 7.6 & 8.6 & & \\
\hline 1 Excluding reserves. ${ }^{2}$ Net claims. & & & \\
Source: IMF International Financial Statistics.
\end{tabular}




\section{Graphs}

Graph 1

Long-term credit rating of major banks *
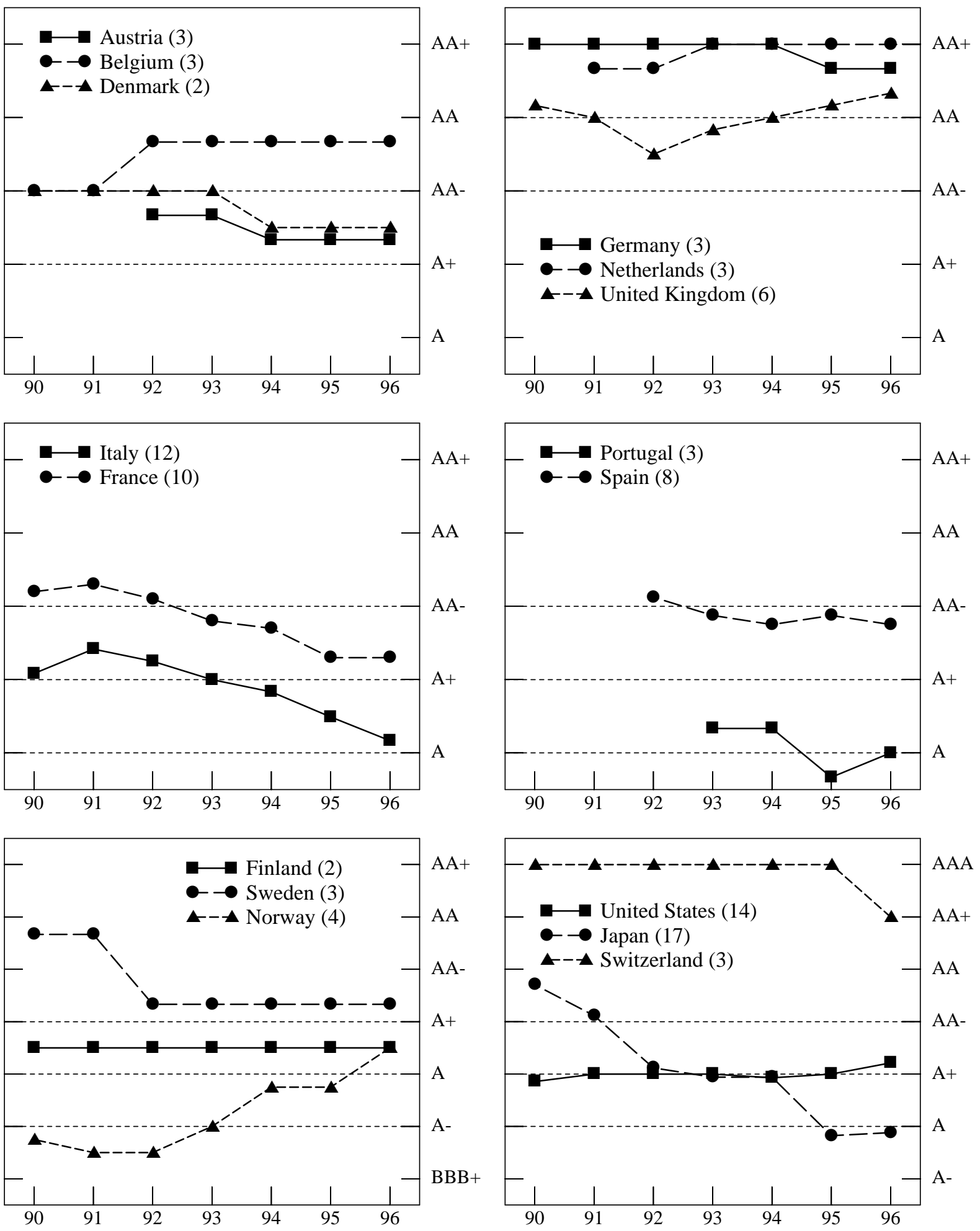

* Average of banks' rating at the end of the year. Data in brackets indicate the number of banks included. Source: IBCA. 


\section{Graph 2a}

\section{Private interest rates in Europe}

In percent per annum

Early January 1995

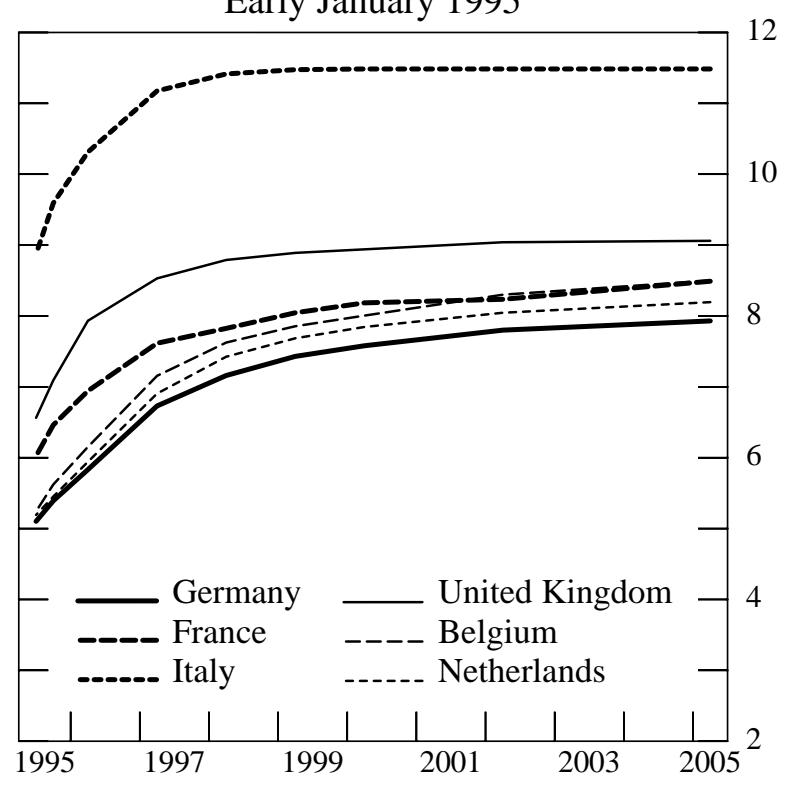

Mid-June 1995

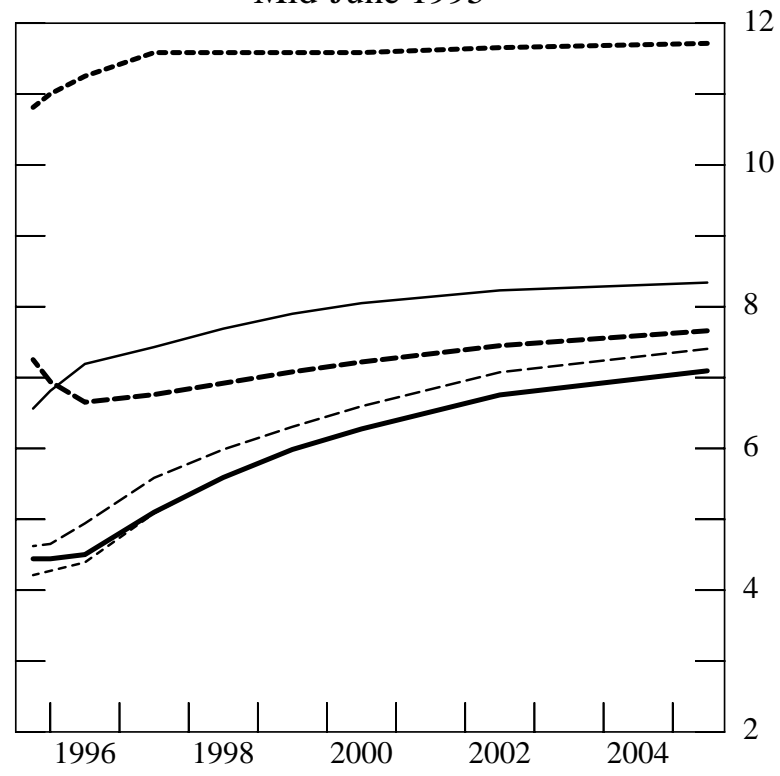

Mid-February 1995

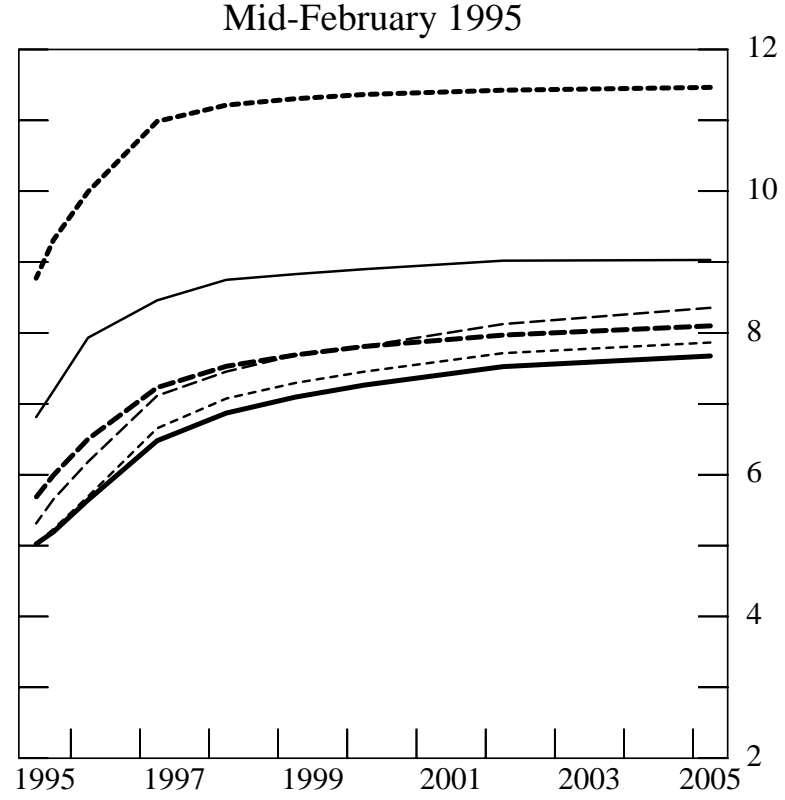

Mid-October 1995

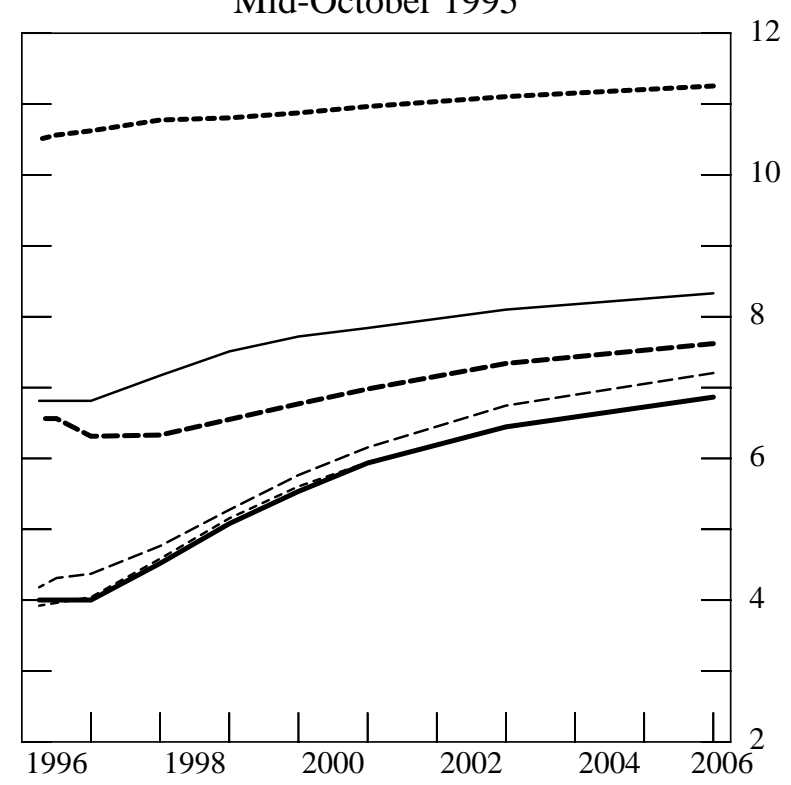

Note: The yield curves are based on eurodeposit rates and, for longer horizons, on swap (midpoint) yields.

Sources: Datastream, Reuters and BIS. 


\section{Private interest rates in Europe}

In percent per annum
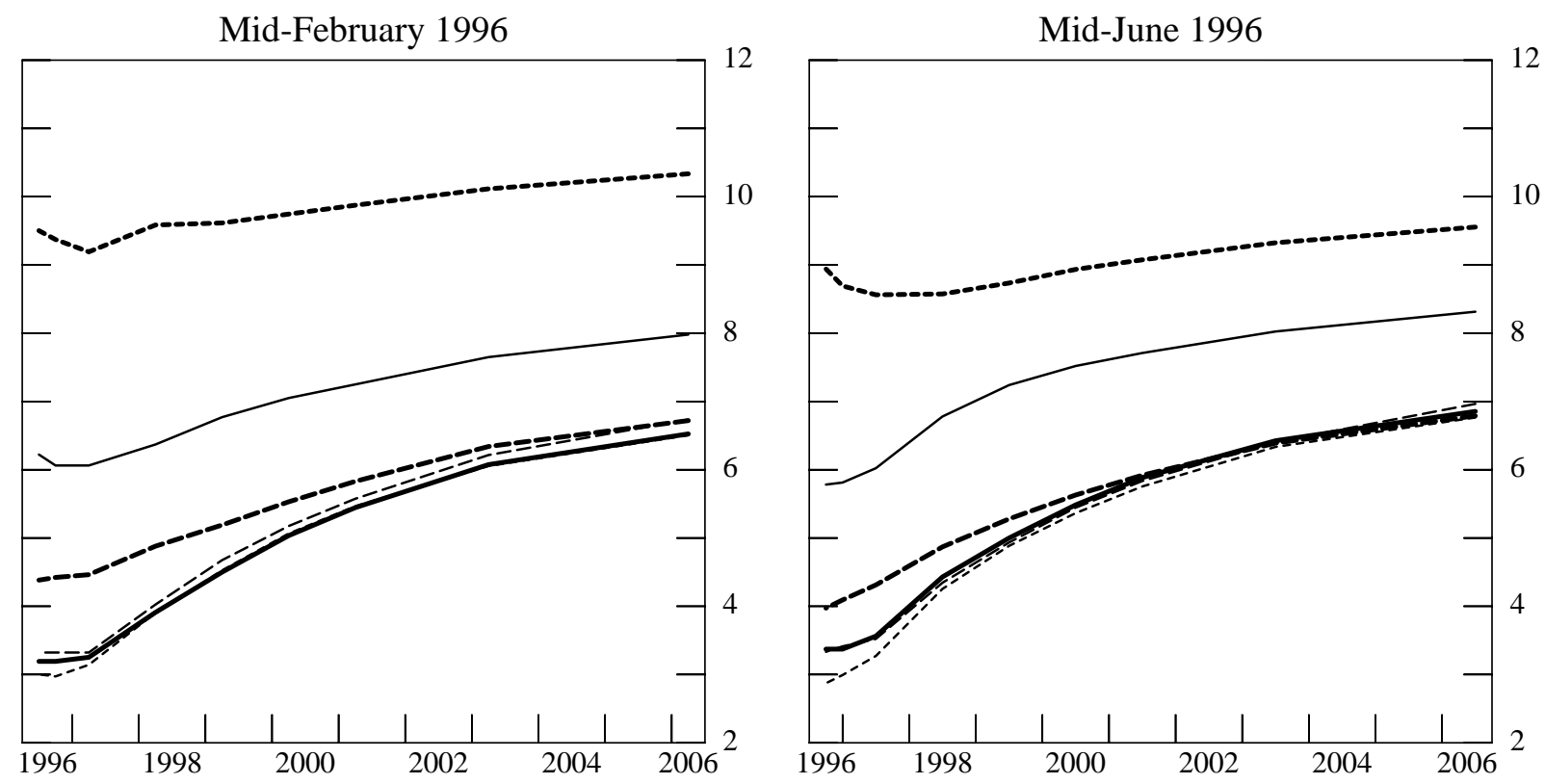

Mid-October 1996

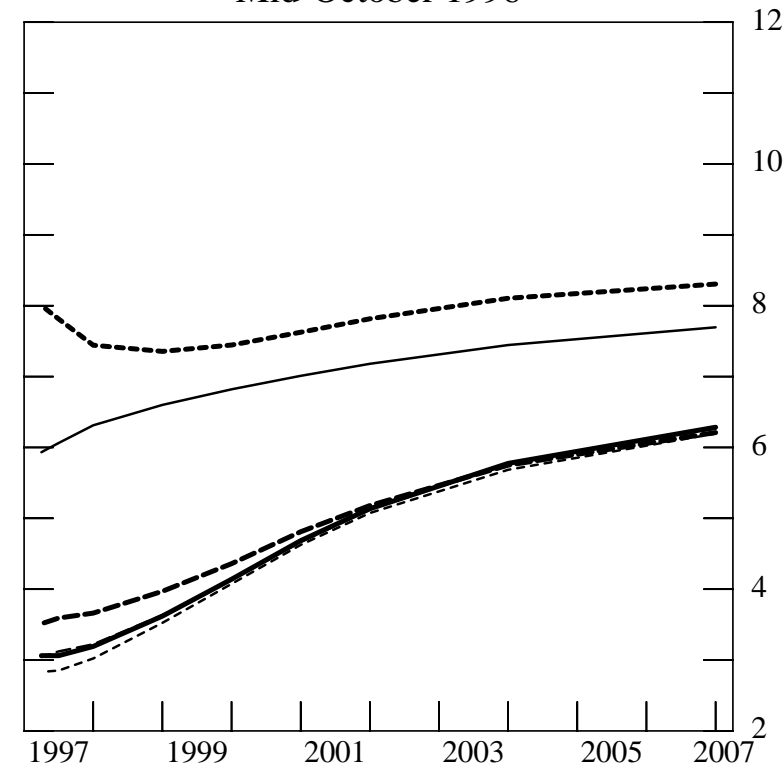

Mid-February 1997

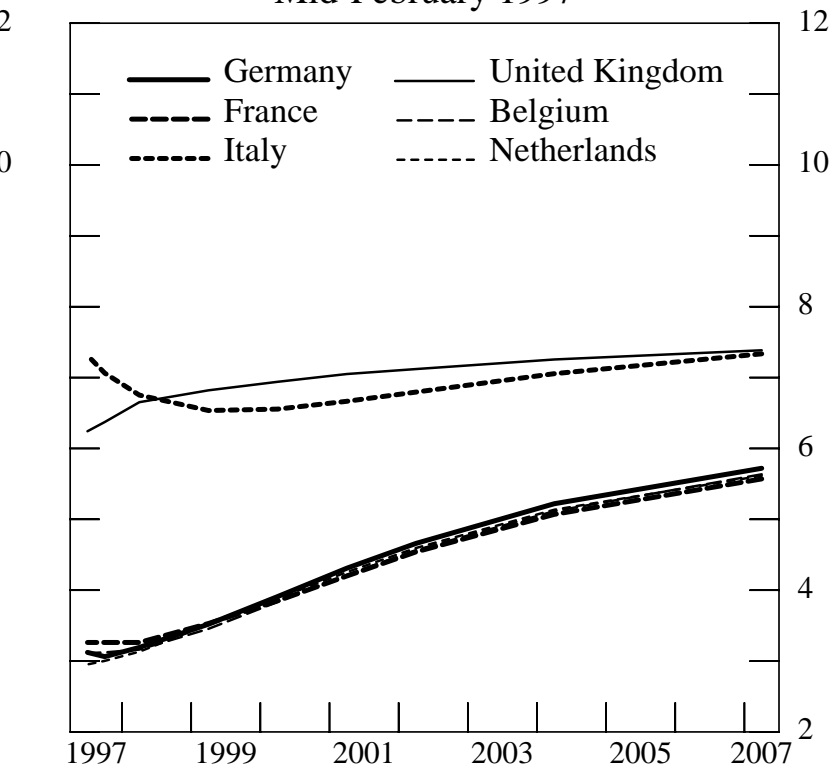

Note: The yield curves are based on eurodeposit rates and, for longer horizons, on swap (midpoint) yields.

Sources: Datastream, Reuters and BIS. 
Graph 3

Spreads of ten-year government yields over interest rate swap yields

Monthly averages, in basis points
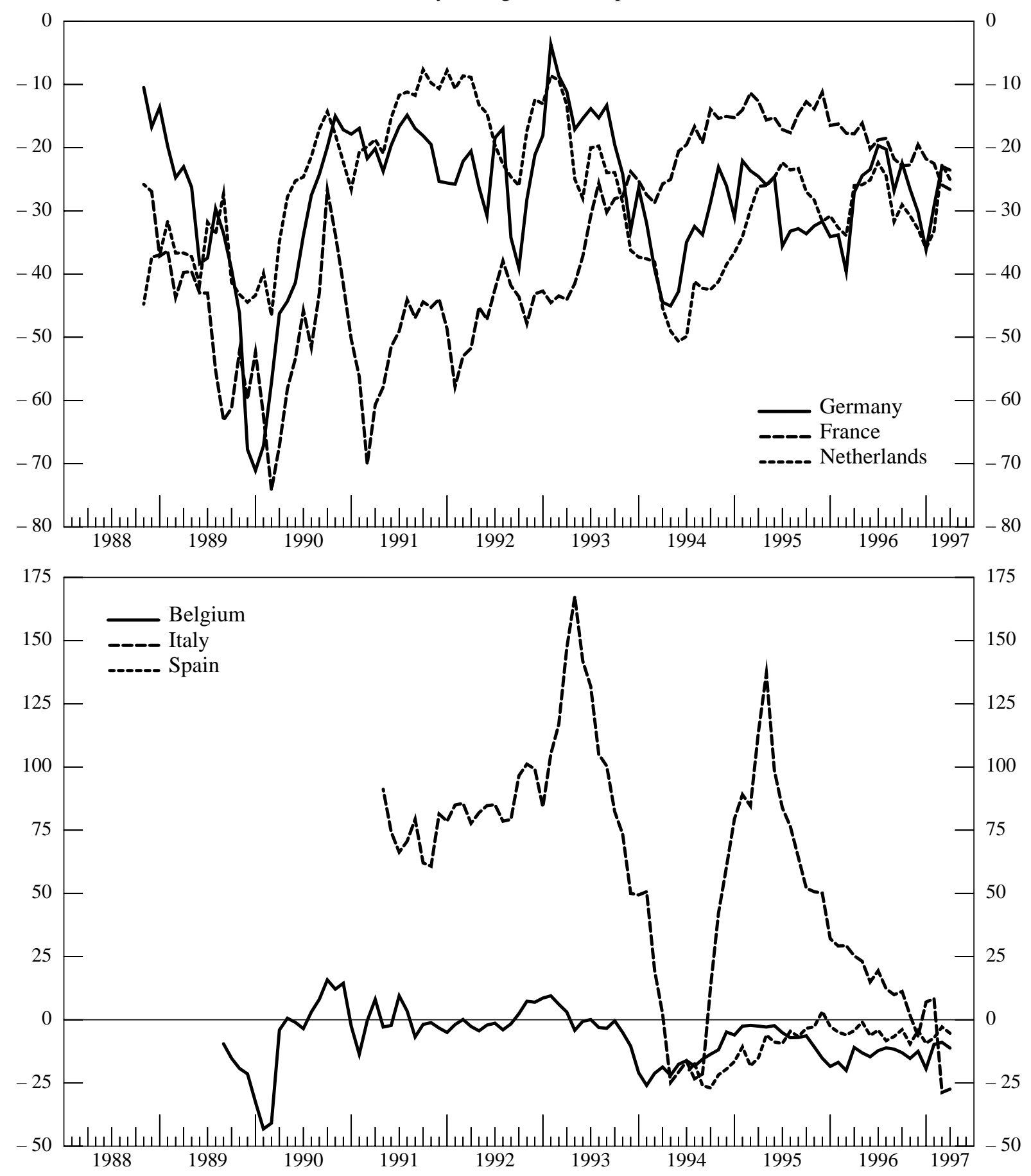

Sources: Datastream and Reuters. 


\section{Graph 4 \\ Credit spreads in the Canadian bond market}

At fourth quarter 1996

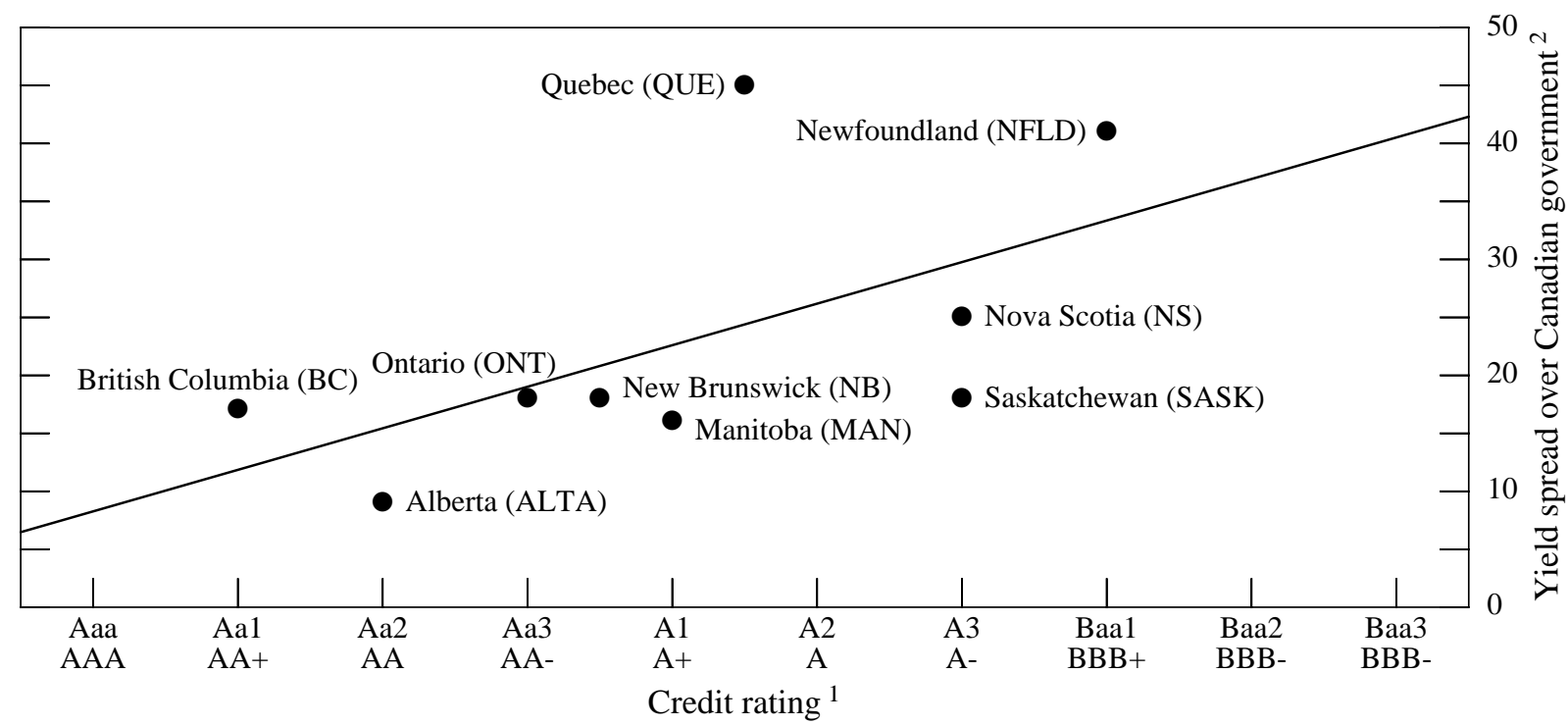

${ }^{1}$ Long-term domestic currency rating; for New Brunswick and Quebec, split rating. ${ }^{2}$ In basis points.

Sources: Moody's, Standard \& Poor's and Morgan Stanley.

Graph 5

\section{Government bond yields in the Canadian and European markets}

Spread over the respective interest-rate swap yields, fourth quarter 1996

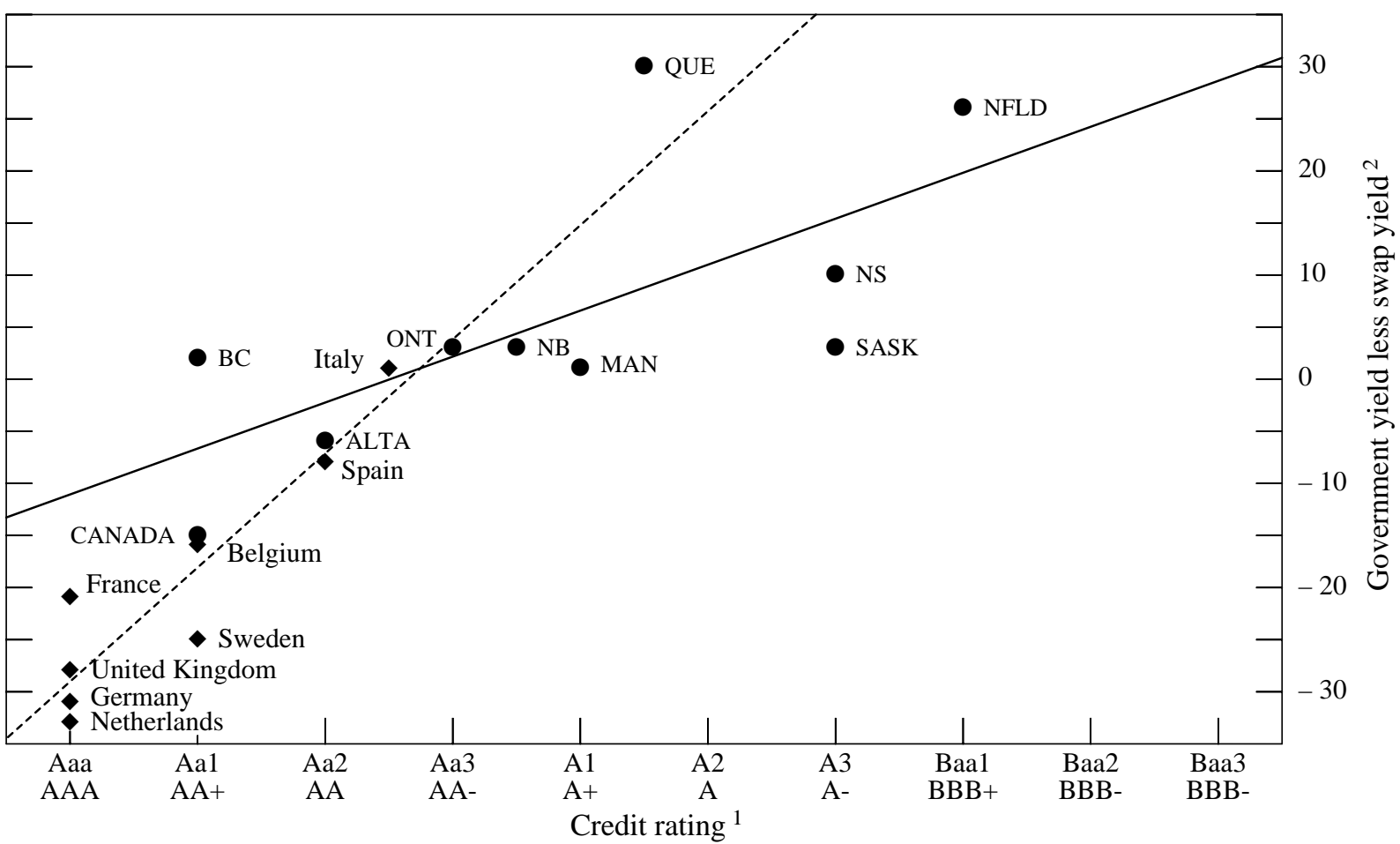

${ }^{1}$ For Canadian provincial governments (including the Commonwealth), see footnote 1 to Graph 4. For European governments, indicated rating in the event of monetary union; for Italy, split rating; for Sweden, no Moody's indication. ${ }^{2}$ In basis points.

Sources: Moody's, Standard \& Poor's and Morgan Stanley. 


\section{Graph 6}

\section{Debt burdens and credit ratings in Canada and Europe}

At fourth quarter 1996

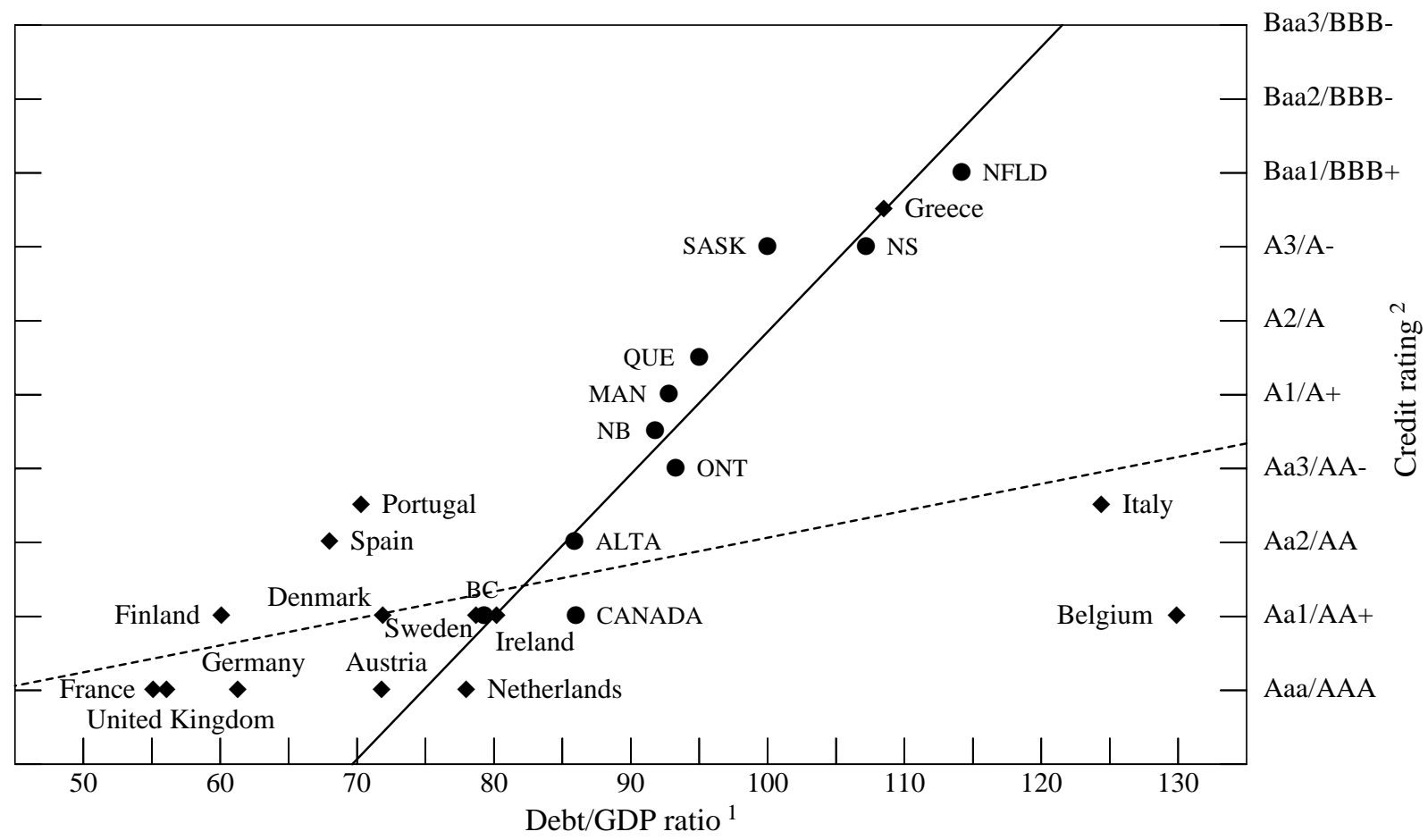

${ }^{1}$ As a percentage. Debt data for European countries are the OECD estimates based on the Maastricht definition. ${ }^{2}$ See footnote 1 to Graph 5; in addition, split rating for Finland, Greece, Ireland and Portugal.

Sources: Morgan Stanley, Moody's, Standard \& Poor's and OECD. 


\section{References}

Adler, Oliver (1996): "EMU and banking". Paper presented at the 1996 ICMB conference Forces of change in international banking, International Center for Monetary and Banking Studies, Geneva, 7th-8th November.

Alworth, Julian and Claudio E.V. Borio (1993): "Commercial paper markets: a survey". BIS Economic Papers no. 37.

Association Cambiste Internationale (1995): The single currency in Europe: a working paper. Paris.

Balder, John, Jose A. Lopez and Lawrence M. Sweet (1991): "Competitiveness in the eurocredit market", in International competitiveness of US financial firms: products, markets, and conventional performance measures. Staff Study, Federal Reserve Bank of New York, May, pp. 26-41.

Banca d'Italia (1995): Ordinary General Meeting of Shareholders. Abridged Report for the year 1994, 31st May.

Bank of England (1996): Practical issues arising from the introduction of the euro, no. 3, 16th December.

Bank for International Settlements (1997): International banking and financial market developments, February.

Bank for International Settlements (1996a): 66th Annual Report, June.

Bank for International Settlements (1996b): Central bank survey of foreign exchange and derivatives market activity 1995, May.

Bank for International Settlements (1996c): International banking and financial market developments, November.

Bank for International Settlements (1995): Financial structure and the monetary policy transmission mechanism, March.

Barran, Fernando, Virginie Coundert and Benoit Mojon (1996): "The transmission of monetary policy in European countries". CEPII document de travail, no. 96-03.

Barth, James R., Daniel E. Nolle and Tara N. Rice (1996): "Commercial banking structure, regulation, and performance: an international comparison". Working Paper (draft), Office of the Comptroller of the Currency.

Beers, David T. (1996): "Stronger-rated sovereigns will lead way into EMU". Standard \& Poor's CreditWeek, 13th November, pp. 13-18.

Benassy-Quéré, Agnés (1996): "Potentialities and opportunities of the euro as an international currency". CEPII document de travail, no. 96-09.

Berlin, Mitchell and Loretta J. Mester (1996): "Why is the banking sector shrinking?" Working Paper no. 96-18, Federal Reserve Bank of Philadelphia. 
Bloem, Mary (1996): "The effect of the euro on European bond markets". Paper presented at a Euromoney seminar on Implications of EMU for the international debt markets, London, 17th-18th October.

Borio, Claudio E.V. and Kostas Tsatsaronis (1996): "Restructuring in banking: the role of mergers and acquisitions". Paper presented at the conference Toward a common European banking market: national strategies and policy issues, Paolo Baffi Centre for Financial and Monetary Economics, Bocconi University, Milan, 10th May.

Bradbery, Adam (1996): "Swap traders say 'sure bet' is uncertain". Wall Street Journal (Europe), 8th May.

Brookes, Martin (1997): "Credit risk and bond yield spreads within EMU". European Economics Analyst, Goldman Sachs, no. 97/07, 26th March.

Brown, Brendon (1996): "EMU: implications for the international debt markets". Paper presented at a Euromoney seminar on Implications of EMU for the international debt markets, London, 17th-18th October.

Bruni, Franco (1990): Banking and financial reregulation: the Italian case", in Jean Dermine (ed.), European banking in the 1990s. Oxford: Blackwell.

Bugie, Scott (1996): "EMU and the banks: costs vs. opportunities". Standard \& Poor's CreditWeek, 13th November.

Bulchandani, Ravi (1996): "Spread economics: interest rates after EMU". Investment Research Europe, Morgan Stanley, 8th November.

Burgess, Arthur (1996): "An issuer's perspective on the European markets pre and post euro". Paper presented at the IBC UK conference Evaluating the impact of the euro on the European securities market, London, 5th-6th November.

Cantor, Richard and Frank Packer (1996): "Determinants and impacts of sovereign credit ratings". Economic Policy Review, Federal Reserve Bank of New York, vol. 2, no. 2, October, pp. 37-53.

Caprio, Gerard and Daniela Klingebiel (1996): "Bank insolvency: bad luck, bad policy, or bad banking?" Paper presented to the Annual World Bank conference on development economics, Washington, DC, 25th-26th April.

Clarke, Ian and Clive Parry (1996): "Government credit spreads too narrow for the post-EMU world?" Morgan Stanley, Fixed Income Portfolio Strategy, 8th October.

Congdon, Tim (1996): "EMU? Not a chance". The Banker, October.

Courtadon, Carol L. (1985): The competitive structure of the eurobond underwriting industry. New York: Salomon Brothers, Center for the Study of Financial Institutions.

Davies, Jonathan (1996): "Assessing the new post-EMU-framework of the fixed income markets". Paper presented at the IIR conference Assessing the practical implications and impact of EMU on the financial markets, London, 18th-19th November.

De Grauwe, Paul (1996): "Forward interest rates as predictors of EMU". CEPR Discussion Paper no. 1395. 
Dermine, Jean (1996): "European banking with a single currency". Financial Markets, Institutions and Instruments, December, pp. 62-102.

Duesing, Jan (1997): "European futures union: what benchmark long futures contract after EMU?" Global Strategy and Relative Value, CS First Boston, London, 19th February.

Economic Research Europe Ltd. (1996): A study of the effectiveness and impact of internal market integration on the banking and credit sector. September.

Eichengreen, Barry and Jürgen von Hagen (1995): "Fiscal policy and monetary union: federalism, fiscal restrictions and the no-bailout rule". CEPR Discussion Paper no. 1247.

European Commission (1997): Draft paper on the technical preparations of the bond markets. Consultative group on the impact of the introduction of the euro on capital markets, March.

Favero, Carlo, Francesco Giavazzi and Luigi Spaventa (1996): "High yields: the spread on German interest rates". CEPR Discussion Paper no. 1330.

Fox, Mark (1996): "The shape of the future euro market". Strategic Investor, Lehman Brothers, 15th August.

Fridson, Martin S. and M. Christopher Garman (1996): "This year in high-yield 1995". Extra Credit, Merrill Lynch, January/February, pp. 4-33.

Gemini Consulting and EFMA (1993): European banking: a view to 2005. London.

Goodhart, Charles (1997): "The two concepts of money, and the future of Europe". Paper presented at the conference Optimum currency areas: the current agenda for international monetary and fiscal integration, organised by the Bank of Israel and the International Monetary Fund in Jerusalem and Tel Aviv, 4th-6th December 1996.

Gregorio, Giuliano (1996): "Weighing up the consequences of EMU on exchange traded derivatives when formally converted into euros". Paper presented at the IIR conference Assessing the practical implications and impact of EMU on the financial markets, London, 18th-19th November.

Gual, Jordi and Damien Neven (1993): "Deregulation of the European banking industry". European Economy/Social Europe, no. 3, pp. 151-183.

Honohan, Patrick (1997): "Financial system failures in developing and transition countries: diagnosis and prediction". BIS Working Papers no. 39.

Hoschka, Tobias C. (1993): Cross-border entry in European retail financial services. New York: St. Martin's Press.

Huteau, Guillaume (1997): "A benchmark swap curve: the full convergence of post-EMU swap curves". Global Strategy and Relative Value, CS First Boston, London, 19th February.

IBCA (1996): The rating impact of EMU, 28th November.

International Law Association (1996): Report by the Committee on International Monetary Law, presented at a meeting of the International Law Association, Helsinki, 31st May. 
Islam, Ifty , Edward Eyerman and Joseph Taylor (1996): "The outlook for intra European spreads after EMU: assessing sovereign credit risk within a monetary union". Global Fixed Income Research, Merrill Lynch, 1st November.

Jeanneau, Serge (1996): "The market for international asset-backed securities". International Banking and Financial Market Developments, BIS, November, pp. 36-46.

Johnson, Christopher (1996): In with the euro, out with the pound: the single currency for Britain. London: Penguin.

Kapstein, Ethan B. (1994): Governing the global economy. Cambridge, MA: Harvard University Press.

Karsenti, René (1996): "EMU: impact on financial markets and practical implications for a large issuer". Paper presented at a Euromoney seminar on Implications of EMU for the international debt markets, London, 17th-18th October.

Keating, Giles (1996): "The politics of sovereign default: an essay on credit spreads after EMU". Economics Research - Europe, CS First Boston, 30th October.

Krämer, Werner (1996): "Impact of the euro for European bond markets". Paper presented at the IBC UK conference Evaluating the impact of the euro on the European securities market, London, 5th-6th November.

Levitt, Malcolm (1995): Economic and monetary union stage III: the issues for banks. London: Centre for the Study of Financial Innovation.

Lipsky, John and colleagues (1996): "Managing convergence: market implications for 1997 and beyond". Economic \& Market Analysis, Salomon Brothers, December.

Livingston, Dorothy and Bill Hutchings (1997): "Legal issues arising from the introduction of the euro". Journal of International Banking Law, February, 12(2).

MATIF Working Committee on the changeover to the euro (1996): Report, December.

Mayer, Thomas (1996): "Volatility, liquidity and demand: preparing for the euro-market". Paper presented at a Euromoney seminar on Implications of EMU for the international debt markets, London, 17th-18th October.

Mazzucchelli, Marco G., Ian Clarke and Clive Parry (1996): "European government bond markets after EMU". Morgan Stanley presentation to the European Commission Consultative Group, Brussels, 25th October.

McCauley, Robert N. (1997): "The euro and the dollar". BIS Working Papers (forthcoming).

McCauley, Robert N. (1996): "Prospects for an integrated European government bond market". International Banking and Financial Market Developments, BIS, August, pp. 28-31.

McCauley, Robert N. (1984): "Maturity matching in the euromarkets". Quarterly Review, Federal Reserve Bank of New York, spring, pp. 36-37.

McCauley Robert N. and Rama Seth (1992): "Foreign bank credit to US corporations: the implications of offshore loans". Quarterly Review, Federal Reserve Bank of New York, spring, pp. 52-65. 
Moody's Investors Service (1997): Credit risk implications of EMU for European sovereign credits, February.

Organisation for Economic Co-operation and Development (1996a): "Institutional investors and financial markets in OECD countries". DAFFE/CMF(96)18/ANN1.

Organisation for Economic Co-operation and Development (1996b): "Public policy and financial market access in the global economy". DAFFE/CMF(96)19/REV1.

Price Waterhouse (1988): "The economics of 1992". European Economy, Brussels, no. 35, March.

Reuss, Konrad (1996): "Standard \& Poor's presentation". Paper presented at a Euromoney seminar on Implications of EMU for the international debt markets, London, 17th-18th October.

Ruocco, John J., Maureen LeBlanc and Patrick Dignan (1991): "Competitiveness in government bond markets" in International competitiveness of US financial firms: products, markets, and conventional performance measures. Staff Study, Federal Reserve Bank of New York, May, pp. $130-155$

Salomon Brothers (1996): "What EMU might mean for European banks". European Equity Research, 29th October.

SBC Warburg (1996): EMU: opportunity or threat?, December.

Schoenmaker, Dirk (1995): "Banking supervision in stage three of EMU". Special Paper no. 72, LSE Financial Markets Group.

Scobie, Hannah M. (1997): The cost and timescale for the switchover to the European single currency for the international securities market. Zurich: European Economics and Financial Centre for the International Securities Market Association.

Serfaty, Bruno (1996): "Risks and opportunities created by EMU in a bond environment". Paper presented at a Euromoney seminar on Implications of EMU for the international debt markets, London, 17th-18th October.

White, William R. (1994): "The implications of the FTA and NAFTA for Canada and Mexico". Technical Report no. 70, Bank of Canada, August.

Zimmer, Steven A. and Robert N. McCauley (1991): "Bank cost of capital and international competition". Quarterly Review, Federal Reserve Bank of New York, winter, pp. 33-59. 



\section{Recent BIS Working Papers}

No.

26

April 1995

27

May 1995

28

August 1995

29

September 1995

30

November 1995

31

December 1995

32

December 1995

33

January 1996

34

January 1996

35

July 1996

36

August 1996

37

September 1996

38

October 1996

39

January 1997

40

March 1997
Title

The monetary transmission mechanism:

evidence from the G-7 countries

The response of short-term bank lending rates to policy

rates: a cross-country perspective

The term structure of Euro-rates: some evidence in support of the expectations hypothesis

The information content of the term structure: evidence for Germany

Money demand stability and currency substitution in six European countries (1980-1992)

Testing the quantity theory using long-run averaged cross-country data

The anatomy of the bond market turbulence of 1994

Derivatives and asset price volatility: a test using variance ratios

Monetary policy and the behaviour of interest rates: are long rates excessively volatile?

Varieties of monetary policy operating procedures: balancing monetary objectives with market efficiency

Estimation of speculative attack models: Mexico yet again

Does the term structure predict recessions?

The international evidence

International agreements in the area of banking and

finance: accomplishments and outstanding issues

Banking system failures in developing and transition countries: diagnosis and prediction

Monetary policy operating procedures industrial countries
Author

Stefan Gerlach

and Frank Smets

Claudio E.V. Borio

and Wilhelm Fritz

Stefan Gerlach

and Frank Smets

Stefan Gerlach

Renato Filosa

Stefan Gerlach

Claudio E.V. Borio

Robert N. McCauley

Benjamin H. Cohen

Stefan Gerlach

Joseph Bisignano

William R. Melick

Henri Bernard and Stefan Gerlach

William R. White

Patrick Honohan

Claudio E. V. Borio 